\title{
Laser Irradiation Alters the Expression Profile of Genes Involved in the Extracellular Matrix In Vitro
}

\author{
Sandra M. Ayuk, Nicolette N. Houreld, and Heidi Abrahamse \\ Laser Research Centre, Faculty of Health Sciences, University of Johannesburg, P.O. Box 17011, Doornfontein 2028, South Africa \\ Correspondence should be addressed to Heidi Abrahamse; habrahamse@uj.ac.za
}

Received 16 April 2014; Accepted 25 May 2014; Published 23 June 2014

Academic Editor: Gerhard Litscher

Copyright (C) 2014 Sandra M. Ayuk et al. This is an open access article distributed under the Creative Commons Attribution License, which permits unrestricted use, distribution, and reproduction in any medium, provided the original work is properly cited.

\begin{abstract}
The extracellular matrix (ECM) forms the basis of every phase in wound healing. Healing may be impaired if some of these components are destroyed. Photobiostimulation has demonstrated a stimulatory response in biological processes. This study aimed to evaluate various genes involved in the ECM, in response to laser irradiation. Isolated human skin fibroblasts were used in three different cell models, namely, normal, normal wounded, and diabetic wounded. Cells were irradiated with $5 \mathrm{~J} / \mathrm{cm}^{2}$ using a continuous wave diode laser emitting at a wavelength of $660 \mathrm{~nm}$ and incubated for $48 \mathrm{~h}$. Nonirradiated $\left(0 \mathrm{~J} / \mathrm{cm}^{2}\right) \mathrm{normal}$ and diabetic wounded cells served as the control. Real-time reverse transcription (RT) quantitative polymerase chain reaction (qPCR) was used to determine the expression of 84 genes in a PCR array. There was a significant upregulation of 29 genes in the normal cells, 32 genes in the normal wounded cells, and 18 genes in the diabetic wounded cells as well as a downregulation of 19 genes (normal), 6 genes (normal wounded), and 31 genes (diabetic wounded). Low intensity laser irradiation (LILI) stimulates gene expression in various cell adhesion molecules (CAMs) and extracellular proteins at $660 \mathrm{~nm}$ in wounded fibroblasts in vitro.
\end{abstract}

\section{Introduction}

Components of the extracellular matrix (ECM) have been shown to be useful in wound healing $[1,2]$. They form the core of every wound healing phase, and healing may be impaired if any of these components is destroyed [3]. In addition, they play a role in angiogenesis, tissue remodelling, and rapid scaffold breakdown [4]. The interaction between the ECM and various cells is very important for proper functioning of the cell [5-8]. This interaction could be direct or indirect. Directly, cellular receptors stimulate the ECM or indirectly, through the structural components of the ECM produced by glycoproteins. Cellular activities directed by these interactions are required for wound healing.

Regulation of the wound healing process comprises the interaction of various cell types, namely, neutrophils, lymphocytes, macrophages, and fibroblasts, and regular mediators such as growth factors and cytokines and ECM components (fibronectin (FN); fibrin; collagen; and elastin (EI)); laminin (LMN); proteoglycans (PG); glycosaminoglycans (GAG); matrix metalloproteinases (MMPs); and tissue inhibitor of metalloproteinases (TIMPs) [2].
For proper cell survival and gene expression in normal wound healing, the environment needs to be at equilibrium with the activity of growth factors, fibroblast interaction, and mechanical forces to ensure normal tissue remodelling [9]. Fibroblasts produce most of the molecules in the ECM including proteases, integrins, cytokines, and growth factors during tissue repair which are responsible for late phase tissue remodelling and eventually scarring $[10,11]$. However, the situation is different in chronic wounds due to the disruption of the regular healing process because of tissue damage, biochemical and cellular imbalances, or an underlying pathological state such as diabetes and venous insufficiency. Venous leg ulcers (VLUs) are amongst the major problems in public health and have become an economic burden in most health care services. It is commonly associated with pain, reduces the quality of life, and is even associated with death. It may also cause tiredness and depression [12-14]. The prevalence of diabetic foot ulcers is approximately $1-2 \%$ worldwide [15]; it occurs at any age [16] with an incidence of $3-5 \%$ over 65 years [17].

Photobiostimulation, or photobiomodulation, is a noninvasive type of treatment that modulates the treatment of 
TABLE 1: Laser parameters.

\begin{tabular}{|c|c|}
\hline \multicolumn{2}{|c|}{ Laser parameters } \\
\hline Wavelength (nm) & 660 \\
\hline Wave emission & Continuous wave \\
\hline Power output (mW) & 92.5 \\
\hline Spot size $\left(\mathrm{cm}^{2}\right)$ & 9.1 \\
\hline Output density $\left(\mathrm{mW} / \mathrm{cm}^{2}\right)$ & 10.22 \\
\hline Irradiation duration & $8 \min 9 s$ \\
\hline Fluence $\left(\mathrm{J} / \mathrm{cm}^{2}\right)$ & 5 \\
\hline
\end{tabular}

TABLE 2: Functional genes of the ECM and its adhesion molecules.

\begin{tabular}{|c|c|}
\hline Pathway & Genes \\
\hline \multicolumn{2}{|r|}{ Cell adhesion molecules } \\
\hline Transmembrane molecules & $\begin{array}{l}\text { CD44, CDH1, HAS1, ICAM1, ITGA1, ITGA2, ITGA3, ITGA4, ITGA5, ITGA6, ITGA7, ITGA8, ITGAL, } \\
\text { ITGAM, ITGAV, ITGB1, ITGB2, ITGB3, ITGB4, ITGB5, MMP14, MMP15, MMP16, NCAM1, PECAM1, } \\
\text { SELE, SELL, SELP, SGCE, SPG7, and VCAM1 }\end{array}$ \\
\hline Cell-cell adhesion & CD44, CDH1, COL11A1, COL14A1, COL6A2, CTNND1, ICAM1, ITGA8, and VCAM1 \\
\hline Cell-matrix adhesion & $\begin{array}{l}\text { ADAMTS13, CD44, ITGA1, ITGA2, ITGA3, ITGA4, ITGA5, ITGA6, ITGA7, ITGA8, ITGAL, ITGAM, } \\
\text { ITGAV, ITGB1, ITGB2, ITGB3, ITGB4, ITGB5, SGCE, SPP1, and THBS3 }\end{array}$ \\
\hline Other adhesion molecules & $\begin{array}{l}\text { CNTN1, COL12A1, COL15A1, COL16A1, COL5A1, COL6A1, COL7A1, COL8A1, VCAN, CTGF, CTNNA1, } \\
\text { CTNNB1, CTNND2, FN1, KAL1, LAMA1, LAMA2, LAMA3, LAMB1, LAMB3, LAMC1, THBS1, THBS2, } \\
\text { CLEC3B, TNC, and VTN }\end{array}$ \\
\hline \multicolumn{2}{|r|}{ Extracellular matrix proteins } \\
\hline $\begin{array}{l}\text { Basement membrane } \\
\text { constituents }\end{array}$ & COL4A2, COL7A1, LAMA1, LAMA2, LAMA3, LAMB1, LAMB3, LAMC1, and SPARC \\
\hline $\begin{array}{l}\text { Collagens and ECM } \\
\text { structural constituents }\end{array}$ & $\begin{array}{l}\text { COL11A1, COL12A1, COL14A1, COL15A1, COL16A1, COL1A1, COL4A2, COL5A1, COL6A1, COL6A2, } \\
\text { COL7A1, COL8A1, FN1, and KAL1 }\end{array}$ \\
\hline ECM proteases & $\begin{array}{l}\text { ADAMTS1, ADAMTS13, ADAMTS8, MMP1, MMP10, MMP11, MMP12, MMP13, MMP14, MMP15, } \\
\text { MMP16, MMP2, MMP3, MMP7, MMP8, MMP9, SPG7, and TIMP1 }\end{array}$ \\
\hline ECM protease inhibitors & COL7A1, KAL1, THBS1, TIMP1, TIMP2, and TIMP3 \\
\hline Other ECM molecules & VCAN, CTGF, ECM1, HAS1, SPP1, TGFBI, THBS2, THBS3, CLEC3B, TNC, and VTN \\
\hline
\end{tabular}

wounds through various cellular or biological processes. It is effective in the visible and near infrared (NIR) spectral range. It functions at wavelengths of $500-1100 \mathrm{~nm}$ and a power output of $10-200 \mathrm{~mW}$ [18]. The use of photobiomodulation in wound healing has greatly ameliorated various cellular processes affecting different phases of wound healing. Studies have demonstrated the stimulatory effects of photobiomodulation in wounded cell models [19] at $660 \mathrm{~nm}$ [20]. Studies have also shown that it enhances diabetic wound healing in both rats and mice [21-23]. Photobiostimulation in the visible and NIR spectral range has been demonstrated to regulate gene expression in human and animal cell cultures, even though its effect was not consistent in all irradiated cells [24]. Studies from different areas showed variations in the gene expression profile of 50 cultures of fibroblasts [25]. Few studies have exploited the relationship of laser irradiation and gene expression of the ECM in fibroblasts in vitro. Due to previous studies which showed an increase in collagen type I (Col-I) in response to laser irradiation at $660 \mathrm{~nm} \mathrm{[20],} \mathrm{this}$ study aimed to determine the effect of laser irradiation at $660 \mathrm{~nm}$ on the gene expression profile of the ECM and its cell adhesion molecules.

\section{Methodology}

2.1. Cell Culture. This study was performed on human skin fibroblasts isolated from a consenting adult undergoing abdominoplasty (Linksfield, Sandringham, Johannesburg) (University of Johannesburg Academic Ethics Committee Clearance Reference number 01/06). Cells were seeded into $3.4 \mathrm{~cm}$ diameter tissue culture flasks at a density of $6 \times 10^{5}$ and routinely cultured according to standard techniques [26]. Different cell models, namely, normal (N), normal wounded (NW), and diabetic wounded (DW), were used. To establish an in vitro diabetic model, $17 \mathrm{mM} / \mathrm{L}$ D-glucose was added to the media with a base concentration of $5.6 \mathrm{mM} / \mathrm{L} \mathrm{D}$ glucose. Thirty minutes prior to irradiation, a sterile $1 \mathrm{~mL}$ disposable pipette was used to scratch the monolayer of cells in a streaking motion (i.e., creating a central scratch (CS)). This creates a cell-free zone on either side of the central scratch $[27,28]$.

2.2. Laser Irradiation. Cells were irradiated with $5 \mathrm{~J} / \mathrm{cm}^{2}$ using a continuous wave diode laser emitting at a wavelength 
TABLE 3: Gene expression profile in normal $(\mathrm{N})$ cells irradiated at $660 \mathrm{~nm}$. Total RNA from nonirradiated $\mathrm{N}$ cells and irradiated $\mathrm{N}$ cells were characterised in triplicate. A fold difference $>1$ is considered as gene upregulation, while a fold difference $<1$ is considered as gene downregulation. Fold differences are indicated as upregulation $(\uparrow)$ or downregulation $(\downarrow)$. X denotes the nonsignificant genes in that particular cell model.

\begin{tabular}{|c|c|c|c|c|c|}
\hline Gene symbol & Gene description & Gene ID & Fold difference & Up/downregulation & $P$ value \\
\hline ADAMTS1 & $\begin{array}{l}\text { ADAM metallopeptidase with thrombospondin } \\
\text { type } 1 \text { motif, } 1\end{array}$ & 9510 & 4.36 & $\uparrow$ & 0.003 \\
\hline ADAMTS13 & $\begin{array}{l}\text { ADAM metallopeptidase with thrombospondin } \\
\text { type } 1 \text { motif, } 13\end{array}$ & 11093 & 1.32 & $\mathrm{X}$ & 0.259 \\
\hline ADAMTS8 & $\begin{array}{l}\text { ADAM metallopeptidase with thrombospondin } \\
\text { type } 1 \text { motif, } 8\end{array}$ & 11095 & 2.77 & $\uparrow$ & 0.003 \\
\hline CD44 & CD44 molecule (Indian blood group) & 960 & 4.85 & $\uparrow$ & 0.012 \\
\hline CDH1 & Cadherin 1, type 1, E-cadherin (epithelial) & 999 & 0.58 & $\downarrow$ & 0.019 \\
\hline CLEC3B & C-type lectin domain family 3 , member B & 7123 & 1.90 & $\mathrm{X}$ & 0.078 \\
\hline CNTN1 & Contactin 1 & 1272 & 1.14 & $\mathrm{X}$ & 0.547 \\
\hline COL11A1 & Collagen, type XI, alpha 1 & 1301 & 1.05 & $\mathrm{X}$ & 0.896 \\
\hline COL12A1 & Collagen, type XII, alpha 1 & 1303 & 2.21 & $\uparrow$ & 0.003 \\
\hline COL14A1 & Collagen, type XIV, alpha 1 & 7373 & 0.56 & $\mathrm{X}$ & 0.116 \\
\hline COL15A1 & Collagen, type XV, alpha 1 & 1306 & 1.33 & $\mathrm{X}$ & 0.198 \\
\hline COL16A1 & Collagen, type XVI, alpha 1 & 1307 & 1.57 & $\mathrm{X}$ & 0.074 \\
\hline COL1A1 & Collagen, type I, alpha 1 & 1277 & 1.88 & $\uparrow$ & 0.001 \\
\hline COL4A2 & Collagen, type IV, alpha 2 & 1284 & 1.78 & $\uparrow$ & 0.022 \\
\hline COL5A1 & Collagen, type V, alpha 1 & 1289 & 4.23 & $\uparrow$ & 0.001 \\
\hline COL6A1 & Collagen, type VI, alpha 1 & 1291 & 2.42 & $\uparrow$ & 0.010 \\
\hline COL6A2 & Collagen, type VI, alpha 2 & 1292 & 3.99 & $\uparrow$ & 0.000 \\
\hline COL7A1 & Collagen, type VII, alpha 1 & 1294 & 1.13 & $\mathrm{X}$ & 0.658 \\
\hline COL8A1 & Collagen, type VIII, alpha 1 & 1295 & 3.07 & $\uparrow$ & 0.000 \\
\hline CTGF & Connective tissue growth factor & 1490 & 0.43 & $\downarrow$ & 0.002 \\
\hline CTNNA1 & $\begin{array}{l}\text { Catenin (cadherin-associated protein), alpha } 1 \text {, } \\
102 \mathrm{kDa}\end{array}$ & 1495 & 0.73 & $\downarrow$ & 0.039 \\
\hline CTNNB1 & $\begin{array}{l}\text { Catenin (cadherin-associated protein), beta } 1 \text {, } \\
88 \mathrm{kDa}\end{array}$ & 1499 & 1.27 & $\mathrm{X}$ & 0.153 \\
\hline CTNND1 & Catenin (cadherin-associated protein), delta 1 & 1500 & 2.21 & $\uparrow$ & 0.001 \\
\hline CTNND2 & $\begin{array}{l}\text { Catenin (cadherin-associated protein), delta } 2 \\
\text { (neural plakophilin-related arm-repeat protein) }\end{array}$ & 1501 & 0.09 & $\downarrow$ & 0.002 \\
\hline ECM1 & Extracellular matrix protein 1 & 1893 & 0.47 & $\downarrow$ & 0.000 \\
\hline FN1 & Fibronectin 1 & 2335 & 2.29 & $\uparrow$ & 0.005 \\
\hline HAS1 & Hyaluronan synthase 1 & 3036 & 1.20 & $\mathrm{X}$ & 0.182 \\
\hline ICAM1 & Intercellular adhesion molecule 1 & 3383 & 0.72 & $\mathrm{X}$ & 0.156 \\
\hline ITGA1 & Integrin, alpha 1 & 3672 & 1.88 & $\uparrow$ & 0.002 \\
\hline ITGA2 & $\begin{array}{l}\text { Integrin, alpha } 2 \text { (CD } 49 \mathrm{~B} \text {, alpha } 2 \text { subunit of } \\
\text { VLA-2 receptor) }\end{array}$ & 3673 & 0.99 & $\mathrm{X}$ & 0.650 \\
\hline ITGA3 & $\begin{array}{l}\text { Integrin, alpha } 3 \text { (antigen CD } 49 \mathrm{C} \text {, alpha } 3 \text { subunit } \\
\text { of VLA-3 receptor) }\end{array}$ & 3675 & 2.98 & $\uparrow$ & 0.000 \\
\hline ITGA4 & $\begin{array}{l}\text { Integrin, alpha } 4 \text { (antigen CD } 49 D \text {, alpha } 4 \text { subunit } \\
\text { of VLA- } 4 \text { receptor) }\end{array}$ & 3676 & 0.81 & $\mathrm{X}$ & 0.193 \\
\hline ITGA5 & $\begin{array}{l}\text { Integrin, alpha } 5 \text { (fibronectin receptor, alpha } \\
\text { polypeptide) }\end{array}$ & 3678 & 3.26 & $\uparrow$ & 0.000 \\
\hline ITGA6 & Integrin, alpha 6 & 3655 & 1.21 & $\mathrm{X}$ & 0.085 \\
\hline ITGA7 & Integrin, alpha 7 & 3679 & 0.92 & $\mathrm{X}$ & 0.780 \\
\hline ITGA8 & Integrin, alpha 8 & 8516 & 1.06 & $\mathrm{X}$ & 0.805 \\
\hline
\end{tabular}


TABle 3: Continued.

\begin{tabular}{|c|c|c|c|c|c|}
\hline Gene symbol & Gene description & Gene ID & Fold difference & Up/downregulation & $P$ value \\
\hline ITGAL & $\begin{array}{l}\text { Integrin, alpha L (antigen CD11A (p180), } \\
\text { lymphocyte function-associated antigen } 1 \text {; alpha } \\
\text { polypeptide) }\end{array}$ & 3683 & 1.06 & $\mathrm{X}$ & 0.540 \\
\hline ITGAM & $\begin{array}{l}\text { Integrin, alpha } \mathrm{M} \text { (complement component } 3 \\
\text { receptor } 3 \text { subunit) }\end{array}$ & 3684 & 1.58 & $\mathrm{X}$ & 0.055 \\
\hline ITGAV & $\begin{array}{l}\text { Integrin, alpha } \mathrm{V} \text { (vitronectin receptor, alpha } \\
\text { polypeptide, antigen CD51) }\end{array}$ & 3685 & 1.17 & $\mathrm{X}$ & 0.331 \\
\hline ITGB1 & $\begin{array}{l}\text { Integrin, beta } 1 \text { (fibronectin receptor, beta } \\
\text { polypeptide, antigen CD29 includes MDF2, } \\
\text { MSK12) }\end{array}$ & 3688 & 0.92 & $\mathrm{X}$ & 0.459 \\
\hline ITGB2 & $\begin{array}{l}\text { Integrin, beta } 2 \text { (complement component } 3 \\
\text { receptor } 3 \text { and } 4 \text { subunit) }\end{array}$ & 3689 & 0.96 & $\mathrm{X}$ & 0.792 \\
\hline ITGB3 & $\begin{array}{l}\text { Integrin, beta } 3 \text { (platelet glycoprotein IIIa, antigen } \\
\text { CD61) }\end{array}$ & 3690 & 1.08 & $\mathrm{X}$ & 0.339 \\
\hline ITGB4 & Integrin, beta 4 & 3691 & 1.25 & $\mathrm{X}$ & 0.127 \\
\hline ITGB5 & Integrin, beta 5 & 3693 & 1.05 & $\mathrm{X}$ & 0.672 \\
\hline KAL1 & Kallmann syndrome 1 sequence & 3730 & 1.53 & $\uparrow$ & 0.030 \\
\hline LAMA1 & Laminin, alpha 1 & 284217 & 0.52 & $\downarrow$ & 0.001 \\
\hline LAMA2 & Laminin, alpha 2 & 3908 & 0.52 & $\downarrow$ & 0.008 \\
\hline LAMA3 & Laminin, alpha 33909 & 3909 & 2.60 & $\uparrow$ & 0.023 \\
\hline LAMB1 & Laminin, beta 1 & 3912 & 0.92 & $\mathrm{X}$ & 0.594 \\
\hline LAMB3 & Laminin, beta 3 & 3914 & 0.55 & $\mathrm{X}$ & 0.069 \\
\hline LAMC1 & Laminin, gamma 1 (formerly LAMB2) & 3915 & 0.83 & $\mathrm{X}$ & 0.063 \\
\hline MMP1 & $\begin{array}{l}\text { Matrix metallopeptidase } 1 \text { (interstitial } \\
\text { collagenase) }\end{array}$ & 4312 & 0.41 & $\downarrow$ & 0.001 \\
\hline MMP10 & Matrix metallopeptidase 10 (stromelysin 2) & 4319 & 0.81 & $\mathrm{X}$ & 0.198 \\
\hline MMP11 & Matrix metallopeptidase 11 (stromelysin 3) & 4320 & 1.53 & $\uparrow$ & 0.015 \\
\hline MMP12 & Matrix metallopeptidase 12 (macrophage elastase) & 4321 & 0.48 & $\downarrow$ & 0.010 \\
\hline MMP13 & Matrix metallopeptidase 13 (collagenase 3) & 4322 & 0.42 & $\downarrow$ & 0.001 \\
\hline MMP14 & Matrix metallopeptidase 14 (membrane-inserted) & 4323 & 4.14 & $\uparrow$ & 0.000 \\
\hline MMP15 & Matrix metallopeptidase 15 (membrane-inserted) & 4324 & 1.96 & $\uparrow$ & 0.000 \\
\hline MMP16 & Matrix metallopeptidase 16 (membrane-inserted) & 4325 & 1.11 & $\mathrm{X}$ & 0.186 \\
\hline MMP2 & $\begin{array}{l}\text { Matrix metallopeptidase } 2 \text { (gelatinase A, } 72 \mathrm{kDa} \\
\text { gelatinase, } 72 \mathrm{kDa} \text { type IV collagenase) }\end{array}$ & 4313 & 3.34 & $\uparrow$ & 0.000 \\
\hline MMP3 & $\begin{array}{l}\text { Matrix metallopeptidase } 3 \text { (stromelysin } 1 \text {, } \\
\text { progelatinase) }\end{array}$ & 4314 & 0.23 & $\downarrow$ & 0.007 \\
\hline MMP7 & Matrix metallopeptidase 7 (matrilysin, uterine) & 4316 & 0.62 & $\downarrow$ & 0.045 \\
\hline MMP8 & $\begin{array}{l}\text { Matrix metallopeptidase } 8 \text { (neutrophil } \\
\text { collagenase) }\end{array}$ & 4317 & 0.75 & $\mathrm{X}$ & 0.112 \\
\hline MMP9 & $\begin{array}{l}\text { Matrix metallopeptidase } 9 \text { (gelatinase } \mathrm{B}, 92 \mathrm{kDa} \\
\text { gelatinase, } 92 \mathrm{kDa} \text { type IV collagenase) }\end{array}$ & 4318 & 0.39 & $\downarrow$ & 0.013 \\
\hline NCAM1 & Neural cell adhesion molecule 1 & 4684 & 1.63 & $\uparrow$ & 0.027 \\
\hline PECAM1 & Platelet/endothelial cell adhesion molecule & 5175 & 0.81 & $\mathrm{X}$ & 0.503 \\
\hline SELE & Selectin E & 6401 & 0.93 & $\mathrm{X}$ & 0.568 \\
\hline SELL & Selectin L & 6402 & 0.99 & $\mathrm{X}$ & 0.961 \\
\hline SELP & $\begin{array}{l}\text { Selectin P (granule membrane protein } 140 \mathrm{kDa} \text {, } \\
\text { antigen CD62) }\end{array}$ & 6403 & 1.35 & $\mathrm{X}$ & 0.469 \\
\hline SGCE & Sarcoglycan, epsilon & 8910 & 0.36 & $\downarrow$ & 0.004 \\
\hline SPARC & $\begin{array}{l}\text { Secreted protein, acidic, cysteine-rich } \\
\text { (osteonectin) }\end{array}$ & 6678 & 3.33 & $\uparrow$ & 0.000 \\
\hline
\end{tabular}


TABLE 3: Continued.

\begin{tabular}{|c|c|c|c|c|c|}
\hline Gene symbol & Gene description & Gene ID & Fold difference & Up/downregulation & $P$ value \\
\hline SPG7 & $\begin{array}{l}\text { Spastic paraplegia } 7 \text { (pure and complicated } \\
\text { autosomal recessive) }\end{array}$ & 6687 & 5.12 & $\uparrow$ & 0.000 \\
\hline SPP1 & Secreted phosphoprotein 1 & 6696 & 0.55 & $\downarrow$ & 0.001 \\
\hline TGFBI & Transforming growth factor, beta-induced, $68 \mathrm{kDa}$ & 7045 & 0.87 & $\mathrm{X}$ & 0.361 \\
\hline THBS1 & Thrombospondin 1 & 7057 & 1.87 & $\uparrow$ & 0.006 \\
\hline THBS2 & Thrombospondin 2 & 7058 & 2.65 & $\uparrow$ & 0.003 \\
\hline THBS3 & Thrombospondin 3 & 7059 & 1.20 & $\mathrm{X}$ & 0.235 \\
\hline TIMP1 & TIMP metallopeptidase inhibitor 1 & 7076 & 1.43 & $\uparrow$ & 0.035 \\
\hline TIMP2 & TIMP metallopeptidase inhibitor 2 & 7077 & 1.17 & $\uparrow$ & 0.025 \\
\hline TIMP3 & TIMP metallopeptidase inhibitor 3 & 7078 & 0.43 & $\downarrow$ & 0.008 \\
\hline TNC & Tenascin C & 3371 & 0.49 & $\downarrow$ & 0.002 \\
\hline VCAM1 & Vascular cell adhesion molecule 1 & 7412 & 0.38 & $\downarrow$ & 0.010 \\
\hline VCAN & Versican & 1462 & 0.46 & $\downarrow$ & 0.008 \\
\hline VTN & Vitronectin & 7448 & 1.12 & $\mathrm{X}$ & 0.585 \\
\hline
\end{tabular}

of $660 \mathrm{~nm}$ (Fremont, CA, USA, RGBlase, TECIRL-100G650SMA); laser parameters are shown in Table 1. All lasers were supplied and set up by the National Laser Centre (NLC) of the Council for Scientific and Industrial Research (CSIR), South Africa. Nonirradiated $\left(0 \mathrm{~J} / \mathrm{cm}^{2}\right)$ normal cells (for irradiated normal and normal wounded) and diabetic wounded cells (for irradiated diabetic wounded cells) served as the control groups. Cells were irradiated from above, with the culture dish lid off, in $1 \mathrm{~mL}$ culture media and in the dark to omit nuisance variables suggestive of polychromatic light that would interfere with the laser effect. The power output was measured using a power meter (FieldMate, 0398D05) at bench level prior to each irradiation, and the readings were used to determine the irradiation time. The temperature of the culture media during irradiation was measured every $2 \mathrm{~min}$ and remained less than $32^{\circ} \mathrm{C}$. Cells were incubated for $48 \mathrm{~h}$, and the profile of genes involved in the ECM and cell adhesion molecules were assessed using a real-time reverse transcription quantitative polymerase chain reaction (RTqPCR) array.

2.3. RNA Isolation and Purity. Isolation of total RNA from the cells was performed on the Qiagen QIAcube (Whitehead Scientific, Cape Town, South Africa) using the RNeasy Mini Kit (Whitehead Scientific, Cape Town, South Africa, Qiagen, 74104) including QIAshredder homogenizers (Whitehead Scientific, Cape Town, South Africa, Qiagen, 79654). After incubation, cell cultures were detached with TrypLE Express $\left(1 \mathrm{~mL} / 25 \mathrm{~cm}^{2}\right.$ ) (Life Technologies, Gibco, Invitrogen, 12605021) and washed with phosphate buffered saline (PBS) to eliminate traces of culture media and then resuspended in $600 \mu \mathrm{L}$ of a guanidine-thiocyanate-containing buffer (RLT buffer) to disrupt the cells, inactivate RNases, and release cellular contents. Within $30 \mathrm{~min}, 30 \mu \mathrm{L}$ of total RNA was eluted and quantified. The concentration of RNA was established using the Quant-iT RNA Assay Kits (Life Technologies, Johannesburg, South Africa, Invitrogen, Q32852) with the Invitrogen Qubit 2.0 fluorometer (Life Technologies,
Johannesburg, South Africa). The ratio between absorbance 260 and $280 \mathrm{~nm}\left(\mathrm{~A}_{260} \mathrm{~nm} / \mathrm{A}_{280} \mathrm{~nm}\right)$ was used to estimate the sample purity using a UV/Vis spectrophotometer (Separation Scientific, Johannesburg, South Africa, PerkinElmer, Victor $\left.^{3}\right)$.

2.4. cDNA Synthesis. According to the protocol, a twostep procedure was used to synthesise cDNA using the QuantiTect Reverse Transcription Kit (Whitehead Scientific, Cape Town, South Africa, Qiagen, 205311). Traces of possible contaminating genomic DNA (gDNA) was eliminated from $1 \mu \mathrm{g}$ purified RNA sample using the gDNA Wipeout Buffer for $2 \mathrm{~min}$ at $42^{\circ} \mathrm{C}$. RNA was then reverse-transcribed using a reverse transcription (RT) master mix. Six microliters of RT master mix was added to the reaction mixture to give a final volume of $20 \mu \mathrm{L}$. The mixture was then incubated for $30 \mathrm{~min}$ at $42^{\circ} \mathrm{C}$ and thereafter $3 \mathrm{~min}$ at $95^{\circ} \mathrm{C}$ to terminate the reaction. One microliter of sample was used to estimate the purity as stated earlier. Samples were stored on ice to proceed directly with real-time qPCR or stored at $-20^{\circ} \mathrm{C}$.

2.5. Gene Expression Profiling. Real-time qPCR was performed using the SABiosciences $\mathrm{RT}^{2}$ profiler PCR array (Whitehead Scientific, Cape Town, South Africa, PAHS01321Z) which profiled 84 genes (Table 2). Ninety-two microliters of PCR water (Diethyl Pyrocarbonate, DEPC free) was added to thawed cDNA $(19 \mu \mathrm{L})$ giving a final volume of $111 \mu \mathrm{L}$. One hundred and two microliters of diluted cDNA was added to the ready-to-use $2 \mathrm{x}$ SABiosciences $\mathrm{RT}^{2}$ qPCR master mix (330521), and then $1248 \mu \mathrm{L}$ of PCR water was added to give a total volume of $2700 \mu \mathrm{L}$. Components were mixed and $25 \mu \mathrm{L}$ of the experimental cocktail was dispensed into each well of the 96-well plate. The sealed PCR plates were centrifuged at $1000 \mathrm{~g}$ (Separation Scientific, Johannesburg, South Africa, Thermo Scientific, Heraeus Labofuge 400) for $1 \mathrm{~min}$ to remove any bubbles and run in the preset real-time thermocycler (Anatech, Randburg, South Africa, Stratagene 
TABLE 4: Gene expression profile in normal wounded (NW) cells irradiated at $660 \mathrm{~nm}$. Total RNA from nonirradiated N cells and irradiated NW cells were characterised in triplicate. A fold difference $>1$ is considered as gene upregulation, while a fold difference $<1$ is considered as gene downregulation. Fold differences are indicated as upregulation $(\uparrow)$ or downregulation $(\downarrow)$. X denotes the nonsignificant genes in that particular cell model.

\begin{tabular}{|c|c|c|c|c|c|}
\hline Gene symbol & Gene description & Gene ID & Fold difference & Up/downregulation & $P$ value \\
\hline ADAMTS1 & $\begin{array}{l}\text { ADAM metallopeptidase with thrombospondin type } 1 \\
\text { motif, } 1\end{array}$ & 9510 & 1.86 & $\uparrow$ & 0.045 \\
\hline ADAMTS13 & $\begin{array}{l}\text { ADAM metallopeptidase with thrombospondin type } 1 \\
\text { motif, } 13\end{array}$ & 11093 & 2.39 & $\uparrow$ & 0.003 \\
\hline ADAMTS8 & $\begin{array}{l}\text { ADAM metallopeptidase with thrombospondin type } 1 \\
\text { motif, } 8\end{array}$ & 11095 & 1.85 & $\uparrow$ & 0.001 \\
\hline CD44 & CD44 molecule (Indian blood group) & 960 & 1.25 & $\mathrm{X}$ & 0.356 \\
\hline $\mathrm{CDH} 1$ & Cadherin 1, type 1, E-cadherin (epithelial) & 999 & 1.23 & $\mathrm{X}$ & 0.205 \\
\hline CLEC3B & C-type lectin domain family 3 , member B & 7123 & 1.15 & $\mathrm{X}$ & 0.299 \\
\hline CNTN1 & Contactin 1 & 1272 & 1.25 & $\mathrm{X}$ & 0.068 \\
\hline COL11A1 & Collagen, type XI, alpha 1 & 1301 & 1.04 & $\mathrm{X}$ & 0.854 \\
\hline COL12A1 & Collagen, type XII, alpha 1 & 1303 & 1.69 & $\uparrow$ & 0.004 \\
\hline COL14A1 & Collagen, type XIV, alpha 1 & 7373 & 0.81 & $\mathrm{X}$ & 0.370 \\
\hline COL15A1 & Collagen, type XV, alpha 1 & 1306 & 1.20 & $\mathrm{X}$ & 0.216 \\
\hline COL16A1 & Collagen, type XVI, alpha 1 & 1307 & 1.05 & $\mathrm{X}$ & 0.749 \\
\hline COL1A1 & Collagen, type I, alpha 1 & 1277 & 1.45 & $\uparrow$ & 0.006 \\
\hline COL4A2 & Collagen, type IV, alpha 2 & 1284 & 1.44 & $\mathrm{X}$ & 0.069 \\
\hline COL5A1 & Collagen, type V, alpha 1 & 1289 & 1.61 & $\uparrow$ & 0.005 \\
\hline COL6A1 & Collagen, type VI, alpha 1 & 1291 & 1.27 & $\mathrm{X}$ & 0.170 \\
\hline COL6A2 & Collagen, type VI, alpha 2 & 1292 & 1.36 & $\mathrm{X}$ & 0.105 \\
\hline COL7A1 & Collagen, type VII, alpha 1 & 1294 & 1.42 & $\uparrow$ & 0.005 \\
\hline COL8A1 & Collagen, type VIII, alpha 1 & 1295 & 1.36 & $\uparrow$ & 0.011 \\
\hline CTGF & Connective tissue growth factor & 1490 & 0.95 & $\mathrm{X}$ & 0.284 \\
\hline CTNNA1 & Catenin (cadherin-associated protein), alpha 1, $102 \mathrm{kDa}$ & 1495 & 1.03 & $\mathrm{X}$ & 0.720 \\
\hline CTNNB1 & Catenin (cadherin-associated protein), beta $1,88 \mathrm{kDa}$ & 1499 & 0.95 & $\mathrm{X}$ & 0.700 \\
\hline CTNND1 & Catenin (cadherin-associated protein), delta 1 & 1500 & 1.36 & $\mathrm{X}$ & 0.105 \\
\hline CTNND2 & $\begin{array}{l}\text { Catenin (cadherin-associated protein), delta } 2 \text { (neural } \\
\text { plakophilin-related arm-repeat protein) }\end{array}$ & 1501 & 0.63 & $\downarrow$ & 0.019 \\
\hline ECM1 & Extracellular matrix protein 1 & 1893 & 0.75 & $\downarrow$ & 0.017 \\
\hline FN1 & Fibronectin 1 & 2335 & 1.63 & $\uparrow$ & 0.012 \\
\hline HAS1 & Hyaluronan synthase 1 & 3036 & 2.00 & $\uparrow$ & 0.005 \\
\hline ICAM1 & Intercellular adhesion molecule 1 & 3383 & 0.78 & $\mathrm{X}$ & 0.139 \\
\hline ITGA1 & Integrin, alpha 1 & 3672 & 1.57 & $\uparrow$ & 0.005 \\
\hline ITGA2 & $\begin{array}{l}\text { Integrin, alpha } 2 \text { (CD } 49 B \text {, alpha } 2 \text { subunit of VLA- } 2 \\
\text { receptor) }\end{array}$ & 3673 & 0.86 & $\mathrm{X}$ & 0.073 \\
\hline ITGA3 & $\begin{array}{l}\text { Integrin, alpha } 3 \text { (antigen CD } 49 \text { C, alpha } 3 \text { subunit of } \\
\text { VLA-3 receptor) }\end{array}$ & 3675 & 1.33 & $\mathrm{X}$ & 0.121 \\
\hline ITGA4 & $\begin{array}{l}\text { Integrin, alpha } 4 \text { (antigen CD } 49 D \text {, alpha } 4 \text { subunit of } \\
\text { VLA- } 4 \text { receptor) }\end{array}$ & 3676 & 1.19 & $\mathrm{X}$ & 0.057 \\
\hline ITGA5 & $\begin{array}{l}\text { Integrin, alpha } 5 \text { (fibronectin receptor, alpha } \\
\text { polypeptide) }\end{array}$ & 3678 & 1.46 & $\uparrow$ & 0.021 \\
\hline ITGA6 & Integrin, alpha 6 & 3655 & 1.55 & $\uparrow$ & 0.016 \\
\hline ITGA7 & Integrin, alpha 7 & 3679 & 0.90 & $\mathrm{X}$ & 0.462 \\
\hline ITGA8 & Integrin, alpha 8 & 8516 & 2.94 & $\uparrow$ & 0.012 \\
\hline ITGAL & $\begin{array}{l}\text { Integrin, alpha L (antigen CD11A (p180), lymphocyte } \\
\text { function-associated antigen 1; alpha polypeptide) } 3683\end{array}$ & 3683 & 2.04 & $\uparrow$ & 0.030 \\
\hline ITGAM & $\begin{array}{l}\text { Integrin, alpha M (complement component } 3 \text { receptor } 3 \\
\text { subunit) } 3684\end{array}$ & 3684 & 1.59 & $\uparrow$ & 0.027 \\
\hline
\end{tabular}


TABle 4: Continued.

\begin{tabular}{|c|c|c|c|c|c|}
\hline Gene symbol & Gene description & Gene ID & Fold difference & Up/downregulation & $P$ value \\
\hline ITGAV & $\begin{array}{l}\text { Integrin, alpha } \mathrm{V} \text { (vitronectin receptor, alpha } \\
\text { polypeptide, antigen CD51) }\end{array}$ & 3685 & 1.43 & $\uparrow$ & 0.013 \\
\hline ITGB1 & $\begin{array}{l}\text { Integrin, beta } 1 \text { (fibronectin receptor, beta polypeptide, } \\
\text { antigen CD29 includes MDF2, MSK12) }\end{array}$ & 3688 & 1.05 & $\mathrm{X}$ & 0.652 \\
\hline ITGB2 & $\begin{array}{l}\text { Integrin, beta } 2 \text { (complement component } 3 \text { receptor } 3 \\
\text { and } 4 \text { subunit) }\end{array}$ & 3689 & 1.17 & $\mathrm{X}$ & 0.259 \\
\hline ITGB3 & $\begin{array}{l}\text { Integrin, beta } 3 \text { (platelet glycoprotein IIIa, antigen } \\
\text { CD61) }\end{array}$ & 3690 & 1.53 & $\uparrow$ & 0.007 \\
\hline ITGB4 & Integrin, beta 4 & 3691 & 1.42 & $\mathrm{X}$ & 0.062 \\
\hline ITGB5 & Integrin, beta 5 & 3693 & 1.07 & $\mathrm{X}$ & 0.539 \\
\hline KAL1 & Kallmann syndrome 1 sequence & 3730 & 1.41 & $\uparrow$ & 0.006 \\
\hline LAMA1 & Laminin, alpha 1 & 284217 & 0.81 & $\mathrm{X}$ & 0.096 \\
\hline LAMA2 & Laminin, alpha 2 & 3908 & 1.01 & $\mathrm{X}$ & 0.921 \\
\hline LAMA3 & Laminin, alpha 33909 & 3909 & 1.33 & $\mathrm{X}$ & 0.546 \\
\hline LAMB1 & Laminin, beta 1 & 3912 & 1.18 & $\mathrm{X}$ & 0.113 \\
\hline LAMB3 & Laminin, beta 3 & 3914 & 0.87 & $\mathrm{X}$ & 0.273 \\
\hline LAMC1 & Laminin, gamma 1 (formerly LAMB2) & 3915 & 0.94 & $\mathrm{X}$ & 0.419 \\
\hline MMP1 & Matrix metallopeptidase 1 (interstitial collagenase) & 4312 & 0.53 & $\downarrow$ & 0.011 \\
\hline MMP10 & Matrix metallopeptidase 10 (stromelysin 2) & 4319 & 1.06 & $\mathrm{X}$ & 0.456 \\
\hline MMP11 & Matrix metallopeptidase 11 (stromelysin 3) & 4320 & 1.60 & $\uparrow$ & 0.009 \\
\hline MMP12 & Matrix metallopeptidase 12 (macrophage elastase) & 4321 & 0.75 & $\mathrm{X}$ & 0.019 \\
\hline MMP13 & Matrix metallopeptidase 13 (collagenase 3) & 4322 & 0.78 & $\mathrm{X}$ & 0.075 \\
\hline MMP14 & Matrix metallopeptidase 14 (membrane-inserted) & 4323 & 0.97 & $\mathrm{X}$ & 0.909 \\
\hline MMP15 & Matrix metallopeptidase 15 (membrane-inserted) & 4324 & 2.66 & $\uparrow$ & 0.000 \\
\hline MMP16 & Matrix metallopeptidase 16 (membrane-inserted) & 4325 & 1.00 & $\mathrm{X}$ & 0.963 \\
\hline MMP2 & $\begin{array}{l}\text { Matrix metallopeptidase } 2 \text { (gelatinase } \mathrm{A}, 72 \mathrm{kDa} \\
\text { gelatinase, } 72 \mathrm{kDa} \text { type IV collagenase) }\end{array}$ & 4313 & 1.52 & $\uparrow$ & 0.004 \\
\hline MMP3 & Matrix metallopeptidase 3 (stromelysin 1, progelatinase) & 4314 & 0.33 & $\downarrow$ & 0.005 \\
\hline MMP7 & Matrix metallopeptidase 7 (matrilysin, uterine) & 4316 & 1.15 & $\mathrm{X}$ & 0.499 \\
\hline MMP8 & Matrix metallopeptidase 8 (neutrophil collagenase) & 4317 & 1.53 & $\uparrow$ & 0.049 \\
\hline MMP9 & $\begin{array}{l}\text { Matrix metallopeptidase } 9 \text { (gelatinase } \mathrm{B}, 92 \mathrm{kDa} \\
\text { gelatinase, } 92 \mathrm{kDa} \text { type IV collagenase) }\end{array}$ & 4318 & 1.02 & $\mathrm{X}$ & 0.803 \\
\hline NCAM1 & Neural cell adhesion molecule 1 & 4684 & 1.09 & $\mathrm{X}$ & 0.475 \\
\hline PECAM1 & Platelet/endothelial cell adhesion molecule & 5175 & 2.24 & $\uparrow$ & 0.009 \\
\hline SELE & Selectin E & 6401 & 1.39 & $\uparrow$ & 0.041 \\
\hline SELL & Selectin L & 6402 & 1.08 & $\mathrm{X}$ & 0.597 \\
\hline SELP & $\begin{array}{l}\text { Selectin P (granule membrane protein } 140 \mathrm{kDa} \text {, antigen } \\
\text { CD62) }\end{array}$ & 6403 & 1.47 & $\uparrow$ & 0.032 \\
\hline SGCE & Sarcoglycan, epsilon & 8910 & 0.73 & $\downarrow$ & 0.034 \\
\hline SPARC & Secreted protein, acidic, cysteine-rich (osteonectin) & 6678 & 1.59 & $\uparrow$ & 0.001 \\
\hline SPG7 & $\begin{array}{l}\text { Spastic paraplegia } 7 \text { (pure and complicated autosomal } \\
\text { recessive) }\end{array}$ & 6687 & 1.28 & $\uparrow$ & 0.042 \\
\hline SPP1 & Secreted phosphoprotein 1 & 6696 & 0.84 & $\mathrm{X}$ & 0.118 \\
\hline TGFBI & Transforming growth factor, beta-induced, $68 \mathrm{kDa}$ & 7045 & 1.10 & $\mathrm{X}$ & 0.317 \\
\hline THBS1 & Thrombospondin 1 & 7057 & 1.59 & $\uparrow$ & 0.008 \\
\hline THBS2 & Thrombospondin 2 & 7058 & 2.04 & $\uparrow$ & 0.004 \\
\hline THBS3 & Thrombospondin 3 & 7059 & 0.89 & $\mathrm{X}$ & 0.349 \\
\hline TIMP1 & TIMP metallopeptidase inhibitor 1 & 7076 & 1.31 & $\mathrm{X}$ & 0.073 \\
\hline TIMP2 & TIMP metallopeptidase inhibitor 2 & 7077 & 1.07 & $\mathrm{X}$ & 0.244 \\
\hline TIMP3 & TIMP metallopeptidase inhibitor 3 & 7078 & 0.89 & $\mathrm{X}$ & 0.340 \\
\hline
\end{tabular}


TABLE 4: Continued.

\begin{tabular}{|c|c|c|c|c|c|}
\hline Gene symbol & Gene description & Gene ID & Fold difference & Up/downregulation & $P$ value \\
\hline TNC & Tenascin C & 3371 & 0.73 & $\downarrow$ & 0.005 \\
\hline VCAM1 & Vascular cell adhesion molecule 1 & 7412 & 0.61 & $\mathrm{X}$ & 0.065 \\
\hline VCAN & Versican & 1462 & 0.87 & $\mathrm{X}$ & 0.252 \\
\hline VTN & Vitronectin & 7448 & 0.62 & $\downarrow$ & 0.024 \\
\hline
\end{tabular}

Mx3000p). The thermocycler profile setting was $10 \mathrm{~min}$ at $95^{\circ} \mathrm{C}$ for $1 \mathrm{cycle}$ and $15 \mathrm{~s}$ at $95^{\circ} \mathrm{C}$ and $1 \mathrm{~min}$ at $60^{\circ} \mathrm{C}$ for 40 cycles. The software was also programmed to do a melt or dissociation curve at the end of the run to ensure the amplification of a single product for each gene. The threshold cycle $\left(C_{t}\right)$ values were imported into an Excel spreadsheet (Available from the SABiosciences website: http://www.sabiosciences.com/) which normalised the results against the 5 housekeeping genes (ACTB, B2M, GAPDH, HPRTI, and RPLPO). In addition, the relative gene expression $\left(\Delta \Delta C_{t}\right)$ and fold change $\left(2^{-\Delta \Delta C_{t}}\right)$ were also calculated. Prior to data analysis, all the $C_{t}$ values of the controls were examined to ensure proper functioning of the PCR array and preceding steps (positive PCR control, $C_{t}$ value of $20 \pm 2$; genomic DNA control, $C_{t}$ value of $>35$ ). A fold change of $>1$ was reported as fold upregulation and a fold change $<1$ was reported as fold downregulation.

2.6. Statistical Analysis. Experiments were repeated three times $(n=3)$. Student's $t$-test was analysed based on the replicate fold change for each gene in both the test and the control groups by the SABiosciences Excel-based data analysis template and reported as significant if $P<0.05$. Results are represented in Tables 3 to 6.

\section{Results}

Irradiation of $\mathrm{N}$ cells with $660 \mathrm{~nm}$ resulted in the significant upregulation of 29 genes and downregulation of 19 genes (Table 3). Irradiation of NW cells with $660 \mathrm{~nm}$ resulted in the significant upregulation of 32 genes and downregulation of 6 genes (Table 4). Irradiation of DW cells with $660 \mathrm{~nm}$ resulted in the upregulation of 18 genes and downregulation of 31 genes (Table 5). A summary of the results is presented in Table 6.

\section{Discussion and Conclusion}

ECM components are very useful in different aspects of wound healing. The ECM interacts with various cells and growth factors in cell proliferation, influencing migration, cell differentiation, and regulating several biological responses $[1,5,6,29,30]$. The effects shown by different ECM components depend on the stage of the wound and are determined by the interactions between the cells and growth factors [29]. There is great need for gene expression profiling in the ECM following laser irradiation to be exploited. In this study, 84 genes related to the ECM were studied in various models. Photoirradiation was shown to stimulate gene expression $48 \mathrm{~h}$ after incubation in irradiated $\mathrm{N}, \mathrm{NW}$, and DW cells as compared to their respective controls. The genes, either up- or downregulated, are functionally grouped depending on their pathways in the ECM.

In the present study, four main CAM families were mediated following irradiation at $660 \mathrm{~nm}$. They include cadherins, integrins, selectins, and immunoglobulin CAM (Ig-CAM). The cadherin family are mainly calcium-dependent glycoproteins containing an extracellular domain, a transmembrane domain, and an intracellular domain [31]. Cadherins and integrins form the main cell-surface transmembrane receptors and are involved in modulating cell-cell and cell-matrix adhesion. They function in various cellular events, namely, cell migration, proliferation, survival, differentiation, and modulation of gene expression profiling $[32,33]$. In irradiated $\mathrm{N}$ cells, CTNND2 was upregulated and CDH1, CTNNA1, and CTNND1 were downregulated at $660 \mathrm{~nm}$; irradiated NW cells showed downregulation of CTNND2; and DW cells showed an upregulation of CDH1 and CTNND2, while CTNND1 was downregulated.

Integrins are the main receptor family in charge of interactions in the ECM and consist of two noncovalent $\alpha$ and $\beta$ subunits; the specific combination of the subunits determines the degree of cell signalling [34]. In irradiated $\mathrm{N}$ cells, ITGA1, ITGA3, ITGA5, and ITGAM were upregulated; in irradiated NW cells, ITGA1, ITGA5, ITGA6, ITGA8, ITGAL, ITGAM, ITGAV, and ITGB3 were upregulated; and in irradiated DW cells, ITGA8, ITGAL, and ITGB3 were upregulated, while ITGA2, ITGA3, ITGA5, ITGA6, ITGB1, and ITGB4 were downregulated.

Selectins consist of an extracellular domain with a calcium-dependent lectin domain, an epidermal growth factor domain, and a hydrophobic transmembrane domain $[35,36]$. Selectins expressed in response to laser irradiation in $\mathrm{N}$ cells included CLEC3B, while NW cells showed an upregulation in SELE, SELL, and SELP and in DW cells there was an upregulation in SELL.

Ig-CAM contains an extracellular domain with $\mathrm{FN}$ repeats, a transmembrane domain, and an intracellular domain [31, 35]. These domains bind with proteins of the ECM, namely, collagen, LMN, and FN, as well as certain integral cell-surface proteins [31]. Members of the Ig-CAM family expressed in response to LILI were CD44, FN1, NCAM1, PECAM1, SGCE, THBS1, THBS2, SPP1, VTN, VCAM1, and CNTN1. In irradiated N cells, CD44, FN1, NCAM1, THBS1, and THBS2 were upregulated, while SGCE, VCAM1, and SPP1 were downregulated following irradiation at $660 \mathrm{~nm}$ as compared to nonirradiated $\mathrm{N}$ cells. In irradiated NW cells, 
TABLE 5: Gene expression profile in diabetic wounded (DW) cells irradiated at $660 \mathrm{~nm}$. Total RNA from nonirradiated DW cells and irradiated DW cells were characterised in triplicate. A fold difference $>1$ is considered as gene upregulation, while a fold difference $<1$ is considered as gene downregulation. Fold differences are indicated as upregulation $(\uparrow)$ or downregulation $(\downarrow)$. X denotes the nonsignificant genes in that particular cell model.

\begin{tabular}{|c|c|c|c|c|c|}
\hline Gene symbol & Gene description & Gene ID & Fold difference & Up/downregulation & $P$ value \\
\hline ADAMTS1 & $\begin{array}{l}\text { ADAM metallopeptidase with thrombospondin type } 1 \\
\text { motif, } 1\end{array}$ & 9510 & 0.50 & $\downarrow$ & 0.003 \\
\hline ADAMTS13 & $\begin{array}{l}\text { ADAM metallopeptidase with thrombospondin type } 1 \\
\text { motif, } 13\end{array}$ & 11093 & 0.91 & $\mathrm{X}$ & 0.589 \\
\hline ADAMTS8 & $\begin{array}{l}\text { ADAM metallopeptidase with thrombospondin type } 1 \\
\text { motif, } 8\end{array}$ & 11095 & 2.75 & $\uparrow$ & 0.005 \\
\hline CD44 & CD44 molecule (Indian blood group) & 960 & 0.53 & $\downarrow$ & 0.049 \\
\hline $\mathrm{CDH} 1$ & Cadherin 1, type 1, E-cadherin (epithelial) & 999 & 2.12 & $\uparrow$ & 0.051 \\
\hline CLEC3B & C-type lectin domain family 3 , member B & 7123 & 1.14 & $\mathrm{X}$ & 0.749 \\
\hline CNTN1 & Contactin 1 & 1272 & 2.19 & $\uparrow$ & 0.041 \\
\hline COL11A1 & Collagen, type XI, alpha 1 & 1301 & 3.68 & $\uparrow$ & 0.002 \\
\hline COL12A1 & Collagen, type XII, alpha 1 & 1303 & 0.37 & $\mathrm{X}$ & 0.003 \\
\hline COL14A1 & Collagen, type XIV, alpha 1 & 7373 & 1.24 & $\uparrow$ & 0.023 \\
\hline COL15A1 & Collagen, type XV, alpha 1 & 1306 & 0.67 & $\mathrm{X}$ & 0.082 \\
\hline COL16A1 & Collagen, type XVI, alpha 1 & 1307 & 0.61 & $\downarrow$ & 0.001 \\
\hline COL1A1 & Collagen, type I, alpha 1 & 1277 & 0.87 & $\mathrm{X}$ & 0.498 \\
\hline COL4A2 & Collagen, type IV, alpha 2 & 1284 & 0.99 & $\mathrm{X}$ & 0.966 \\
\hline COL5A1 & Collagen, type V, alpha 1 & 1289 & 0.56 & $\downarrow$ & 0.036 \\
\hline COL6A1 & Collagen, type VI, alpha 1 & 1291 & 0.64 & $\downarrow$ & 0.015 \\
\hline COL6A2 & Collagen, type VI, alpha 2 & 1292 & 0.58 & $\downarrow$ & 0.014 \\
\hline COL7A1 & Collagen, type VII, alpha 1 & 1294 & 0.36 & $\downarrow$ & 0.017 \\
\hline COL8A1 & Collagen, type VIII, alpha 1 & 1295 & 0.71 & $\mathrm{X}$ & 0.271 \\
\hline CTGF & Connective tissue growth factor & 1490 & 1.10 & $\mathrm{X}$ & 0.521 \\
\hline CTNNA1 & Catenin (cadherin-associated protein), alpha $1,102 \mathrm{kDa}$ & 1495 & 0.83 & $\mathrm{X}$ & 0.340 \\
\hline CTNNB1 & Catenin (cadherin-associated protein), beta $1,88 \mathrm{kDa}$ & 1499 & 0.64 & $\mathrm{X}$ & 0.084 \\
\hline CTNND1 & Catenin (cadherin-associated protein), delta 1 & 1500 & 0.36 & $\downarrow$ & 0.005 \\
\hline CTNND2 & $\begin{array}{l}\text { Catenin (cadherin-associated protein), delta } 2 \text { (neural } \\
\text { plakophilin-related arm-repeat protein) }\end{array}$ & 1501 & 2.72 & $\uparrow$ & 0.052 \\
\hline ECM1 & Extracellular matrix protein 1 & 1893 & 0.74 & $\mathrm{X}$ & 0.076 \\
\hline FN1 & Fibronectin 1 & 2335 & 0.58 & $\downarrow$ & 0.008 \\
\hline HAS1 & Hyaluronan synthase 1 & 3036 & 0.87 & $\mathrm{X}$ & 0.544 \\
\hline ICAM1 & Intercellular adhesion molecule 1 & 3383 & 0.97 & $\mathrm{X}$ & 0.843 \\
\hline ITGA1 & Integrin, alpha 1 & 3672 & 0.97 & $\mathrm{X}$ & 0.721 \\
\hline ITGA2 & $\begin{array}{l}\text { Integrin, alpha } 2 \text { (CD } 49 B \text {, alpha } 2 \text { subunit of VLA-2 } \\
\text { receptor) }\end{array}$ & 3673 & 0.52 & $\downarrow$ & 0.015 \\
\hline ITGA3 & $\begin{array}{l}\text { Integrin, alpha } 3 \text { (antigen CD } 49 \text { C, alpha } 3 \text { subunit of } \\
\text { VLA-3 receptor) }\end{array}$ & 3675 & 0.50 & $\downarrow$ & 0.010 \\
\hline ITGA4 & $\begin{array}{l}\text { Integrin, alpha } 4 \text { (antigen CD } 49 D \text {, alpha } 4 \text { subunit of } \\
\text { VLA- } 4 \text { receptor) }\end{array}$ & 3676 & 0.86 & $\mathrm{X}$ & 0.459 \\
\hline ITGA5 & $\begin{array}{l}\text { Integrin, alpha } 5 \text { (fibronectin receptor, alpha } \\
\text { polypeptide) }\end{array}$ & 3678 & 0.54 & $\downarrow$ & 0.004 \\
\hline ITGA6 & Integrin, alpha 6 & 3655 & 0.76 & $\downarrow$ & 0.012 \\
\hline ITGA7 & Integrin, alpha 7 & 3679 & 1.11 & $\mathrm{X}$ & 0.513 \\
\hline ITGA8 & Integrin, alpha 8 & 8516 & 2.75 & $\uparrow$ & 0.051 \\
\hline ITGAL & $\begin{array}{l}\text { Integrin, alpha L (antigen CD11A (p180), lymphocyte } \\
\text { function-associated antigen 1; alpha polypeptide) } 3683\end{array}$ & 3683 & 1.89 & $\uparrow$ & 0.003 \\
\hline ITGAM & $\begin{array}{l}\text { Integrin, alpha M (complement component } 3 \text { receptor } 3 \\
\text { subunit) }\end{array}$ & 3684 & 1.77 & $\mathrm{X}$ & 0.065 \\
\hline
\end{tabular}


TABLe 5: Continued.

\begin{tabular}{|c|c|c|c|c|c|}
\hline Gene symbol & Gene description & Gene ID & Fold difference & Up/downregulation & $P$ value \\
\hline ITGAV & $\begin{array}{l}\text { Integrin, alpha } \mathrm{V} \text { (vitronectin receptor, alpha } \\
\text { polypeptide, antigen CD51) }\end{array}$ & 3685 & 0.50 & $\downarrow$ & 0.002 \\
\hline ITGB1 & $\begin{array}{l}\text { Integrin, beta } 1 \text { (fibronectin receptor, beta polypeptide, } \\
\text { antigen CD29 includes MDF2, MSK12) }\end{array}$ & 3688 & 0.53 & $\downarrow$ & 0.005 \\
\hline ITGB2 & $\begin{array}{l}\text { Integrin, beta } 2 \text { (complement component } 3 \text { receptor } 3 \\
\text { and } 4 \text { subunit) }\end{array}$ & 3689 & 1.58 & $\mathrm{X}$ & 0.083 \\
\hline ITGB3 & $\begin{array}{l}\text { Integrin, beta } 3 \text { (platelet glycoprotein IIIa, antigen } \\
\text { CD61) }\end{array}$ & 3690 & 0.58 & $\downarrow$ & 0.006 \\
\hline ITGB4 & Integrin, beta 4 & 3691 & 1.87 & $\uparrow$ & 0.041 \\
\hline ITGB5 & Integrin, beta 5 & 3693 & 0.97 & $\mathrm{X}$ & 0.879 \\
\hline KAL1 & Kallmann syndrome 1 sequence & 3730 & 0.41 & $\downarrow$ & 0.001 \\
\hline LAMA1 & Laminin, alpha 1 & 284217 & 0.60 & $\downarrow$ & 0.014 \\
\hline LAMA2 & Laminin, alpha 2 & 3908 & 1.17 & $\mathrm{X}$ & 0.396 \\
\hline LAMA3 & Laminin, alpha 3 & 3909 & 2.25 & $\uparrow$ & 0.031 \\
\hline LAMB1 & Laminin, beta 1 & 3912 & 0.95 & $\mathrm{X}$ & 0.609 \\
\hline LAMB3 & Laminin, beta 3 & 3914 & 0.61 & $\downarrow$ & 0.010 \\
\hline LAMC1 & Laminin, gamma 1 (formerly LAMB2) & 3915 & 0.54 & $\downarrow$ & 0.008 \\
\hline MMP1 & Matrix metallopeptidase 1 (interstitial collagenase) & 4312 & 0.38 & $\downarrow$ & 0.001 \\
\hline MMP10 & Matrix metallopeptidase 10 (stromelysin 2) & 4319 & 1.28 & $\mathrm{X}$ & 0.271 \\
\hline MMP11 & Matrix metallopeptidase 11 (stromelysin 3) & 4320 & 1.71 & $\uparrow$ & 0.025 \\
\hline MMP12 & Matrix metallopeptidase 12 (macrophage elastase) & 4321 & 0.52 & $\downarrow$ & 0.005 \\
\hline MMP13 & Matrix metallopeptidase 13 (collagenase 3) & 4322 & 1.89 & $\uparrow$ & 0.034 \\
\hline MMP14 & Matrix metallopeptidase 14 (membrane-inserted) & 4323 & 0.44 & $\downarrow$ & 0.016 \\
\hline MMP15 & Matrix metallopeptidase 15 (membrane-inserted) & 4324 & 1.24 & $\mathrm{X}$ & 0.157 \\
\hline MMP16 & Matrix metallopeptidase 16 (membrane-inserted) & 4325 & 0.44 & $\downarrow$ & 0.003 \\
\hline MMP2 & $\begin{array}{l}\text { Matrix metallopeptidase } 2 \text { (gelatinase } \mathrm{A}, 72 \mathrm{kDa} \\
\text { gelatinase, } 72 \mathrm{kDa} \text { type IV collagenase) }\end{array}$ & 4313 & 0.54 & $\downarrow$ & 0.002 \\
\hline MMP3 & Matrix metallopeptidase 3 (stromelysin 1, progelatinase) & 4314 & 2.42 & $\uparrow$ & 0.009 \\
\hline MMP7 & Matrix metallopeptidase 7 (matrilysin, uterine) & 4316 & 1.86 & $\uparrow$ & 0.024 \\
\hline MMP8 & Matrix metallopeptidase 8 (neutrophil collagenase) & 4317 & 0.63 & $\downarrow$ & 0.029 \\
\hline MMP9 & $\begin{array}{l}\text { Matrix metallopeptidase } 9 \text { (gelatinase } \mathrm{B}, 92 \mathrm{kDa} \\
\text { gelatinase, } 92 \mathrm{kDa} \text { type IV collagenase) }\end{array}$ & 4318 & 1.47 & $\uparrow$ & 0.009 \\
\hline NCAM1 & Neural cell adhesion molecule 1 & 4684 & 0.97 & $\mathrm{X}$ & 0.811 \\
\hline PECAM1 & Platelet/endothelial cell adhesion molecule & 5175 & 3.66 & $\mathrm{X}$ & 0.213 \\
\hline SELE & Selectin E & 6401 & 1.50 & $\mathrm{X}$ & 0.078 \\
\hline SELL & Selectin L & 6402 & 2.36 & $\uparrow$ & 0.013 \\
\hline SELP & $\begin{array}{l}\text { Selectin P (granule membrane protein } 140 \mathrm{kDa} \text {, antigen } \\
\text { CD62) }\end{array}$ & 6403 & 1.90 & $\mathrm{X}$ & 0.249 \\
\hline SGCE & Sarcoglycan, epsilon & 8910 & 0.93 & $\mathrm{X}$ & 0.657 \\
\hline SPARC & Secreted protein, acidic, cysteine-rich (osteonectin) & 6678 & 0.66 & $\downarrow$ & 0.054 \\
\hline SPG7 & $\begin{array}{l}\text { Spastic paraplegia } 7 \text { (pure and complicated autosomal } \\
\text { recessive) }\end{array}$ & 6687 & 0.48 & $\downarrow$ & 0.005 \\
\hline SPP1 & Secreted phosphoprotein 1 & 6696 & 0.58 & $\downarrow$ & 0.009 \\
\hline TGFBI & Transforming growth factor, beta-induced, $68 \mathrm{kDa}$ & 7045 & 0.79 & $\mathrm{X}$ & 0.099 \\
\hline THBS1 & Thrombospondin 1 & 7057 & 0.35 & $\downarrow$ & 0.001 \\
\hline THBS2 & Thrombospondin 2 & 7058 & 0.81 & $\mathrm{X}$ & 0.088 \\
\hline THBS3 & Thrombospondin 3 & 7059 & 1.03 & $\mathrm{X}$ & 0.794 \\
\hline TIMP1 & TIMP metallopeptidase inhibitor 1 & 7076 & 1.47 & $\uparrow$ & 0.046 \\
\hline
\end{tabular}


TABLE 5: Continued.

\begin{tabular}{|c|c|c|c|c|c|}
\hline Gene symbol & Gene description & Gene ID & Fold difference & Up/downregulation & $P$ value \\
\hline TIMP2 & TIMP metallopeptidase inhibitor 2 & 7077 & 0.93 & $\mathrm{X}$ & 0.788 \\
\hline TIMP3 & TIMP metallopeptidase inhibitor 3 & 7078 & 1.05 & $\mathrm{X}$ & 0.825 \\
\hline TNC & Tenascin C & 3371 & 1.18 & $\mathrm{X}$ & 0.492 \\
\hline VCAM1 & Vascular cell adhesion molecule 1 & 7412 & 1.79 & $\uparrow$ & 0.002 \\
\hline VCAN & Versican & 1462 & 0.96 & $\mathrm{X}$ & 0.775 \\
\hline VTN & Vitronectin & 7448 & 1.20 & $\mathrm{X}$ & 0.240 \\
\hline
\end{tabular}

FN1, PECAM1, THBS1, and THBS2 were upregulated, while SGCE and VTN were downregulated at $660 \mathrm{~nm}$ as compared to nonirradiated $\mathrm{N}$ cells. In irradiated DW cells, CNTN1 and VCAM1 were upregulated, while CD44, FN1, THBS1, and SPP1 were downregulated at $660 \mathrm{~nm}$ as compared to nonirradiated DW cells. Other adhesion molecules expressed in response to LILI were HAS1, VCAN, TNC, KAL1, and CTGF. In this study, KAL1 was upregulated while TNC, VCAN, and CTGF were downregulated in irradiated $\mathrm{N}$ cells. In irradiated NW cells, HAS1 and KAL1 were upregulated and TNC was downregulated. In irradiated DW cells, KAL1 was upregulated at $660 \mathrm{~nm}$ as compared to nonirradiated DW cells.

ECM proteins including collagen, LMN, EI, proteoglycans, and FN have both adhesive and structural functions. The ECM maintains skin integrity and homeostasis and interacts with several structural and extracellular proteins. Collagen is encoded for by more than 42 genes [29, 37]. Some of the collagen molecules are formed through the interaction between FN and integrins [38, 39]. Collagens are extracellular proteins produced mainly by fibroblasts, divided into two main classes, namely, the nonfibril forming (collagens types IV, VI, VII, and XI) and the fibril forming collagens distinguished by their triple helix (collagens types I, II, III, V, and XI). Their main function is to maintain the structural integrity of various tissues and to strengthen and reorganise the ECM [40]. In this study, COL1A1, COL4A2, COL5A1, COL6A1, COL6A2, COL8A1, and COL12A1 were upregulated in irradiated $\mathrm{N}$ cells. In irradiated $\mathrm{NW}$ cells, COL1A1, COL5A1, COL7A1, COL8A1, and COL12A1 were upregulated, while in DW cells COL11A1 and COL14A1 were upregulated and COL5A1, COL6A1, COL6A2, COL7A1, COL12A1, and COL16A1 were downregulated.

LMNs are basement membrane proteins made up of three nonidentical chains. They are associated with cell adhesion, differentiation, migration, matrix organisation, and signal transduction. LAMA1 was upregulated in irradiated $\mathrm{N}$ cells, while LAMA2 and LAMA3 were downregulated. In irradiated DW cells LAMA3 was upregulated and LAMA1, LAMB3, and LAMC1 were downregulated. Other matrix associated proteins, such as secreted protein, acidic, and cysteine-rich (encoded for by SPARC), spastic paraplegin 7 (encoded for by SPG7), and extracellular matrix protein 1 , were also evaluated. SPARC is associated with cell structure organisation, cell migration, and ECM synthesis [41, 42]. SPG7 is involved in the breakdown of incorrectly folded proteins intracellular motility, membrane trafficking, and organelle biogenesis [43].
ECM1 is part of a cluster of genes involved in epidermal differentiation. Irradiation of N and NW cells to $660 \mathrm{~nm}$ resulted in an upregulation of SPARC and SPG7 and a downregulation in ECM1. Analysis of the gene profile of irradiated DW cells revealed a significant downregulation of SPARC and SPG7. Significantly increased gene expression of the constituents of the basement membrane was observed at $660 \mathrm{~nm}$ in N and NW cells, while DW cells showed a decrease in gene regulation, with most of the genes downregulated.

MMPs are metalloproteases involved in the degradation of the ECM and can be affected in normal or pathological tissue remodelling and wound healing with different substrates, mostly collagen. MMPs are inhibited by TIMPs. ADAMTS (a disintegrin and metalloproteinase with thrombospondin motifs) is a family of 19 peptidases that are involved in the processing of procollagen, connective tissue organization, and cell migration [44-48]. The gene profile for ECM proteases and inhibitors in response to irradiation at $660 \mathrm{~nm}$ revealed an upregulation in MMP2, MMP11, MMP14, MMP15, ADAMTS1, ADAMTS8, TIMP1, TIMP2, and TIMP3 and a downregulation in MMP1, MMP3, MMP7, MMP9, MMP12, and MMP13 in N cells. Irradiated NW cells showed an upregulation of MMP2, MMP8, MMP11, MMP15, ADAMTS1, ADAMTS8, and ADAMTS13, while MMP1, MMP3, and MMP12 showed a downregulation as compared to nonirradiated $\mathrm{N}$ cells. In irradiated DW cells, MMP3, MMP7, MMP9, MMP11, MMP13, ADAMTS8, and TIMP1 were upregulated, while ADAMTS1, MMP1, MMP2, MMP12, MMP14, and MMP16 were downregulated as compared to nonirradiated DW cells.

These results demonstrated changes in gene expression within the different irradiated N, NW, and DW cell models. The genetic profile seen in the $\mathrm{N}$ cell model is a normal response of fibroblast cells to laser irradiation at $660 \mathrm{~nm}$ with $5 \mathrm{~J} / \mathrm{cm}^{2}$. On the other hand, cells in the NW and DW models have been stressed and compromised in some way, and the genetic profile seen in these cells is a response of wounded/stressed fibroblast cells to laser irradiation at $660 \mathrm{~nm}$. Mechanical modulation of these cells would increase upregulation of ECM components, ECM-specific receptors, and enhanced expression of several cytokines and growth factors in a time-dependent manner [49-51]. The present study showed that DW cells had a significantly downregulated gene expression profile as compared to N and NW cells when irradiated at $660 \mathrm{~nm}$. The downregulation of most of the genes in DW cells is probably due to the dysfunctioning of the ECM exhibited in chronic wounds as a result of 


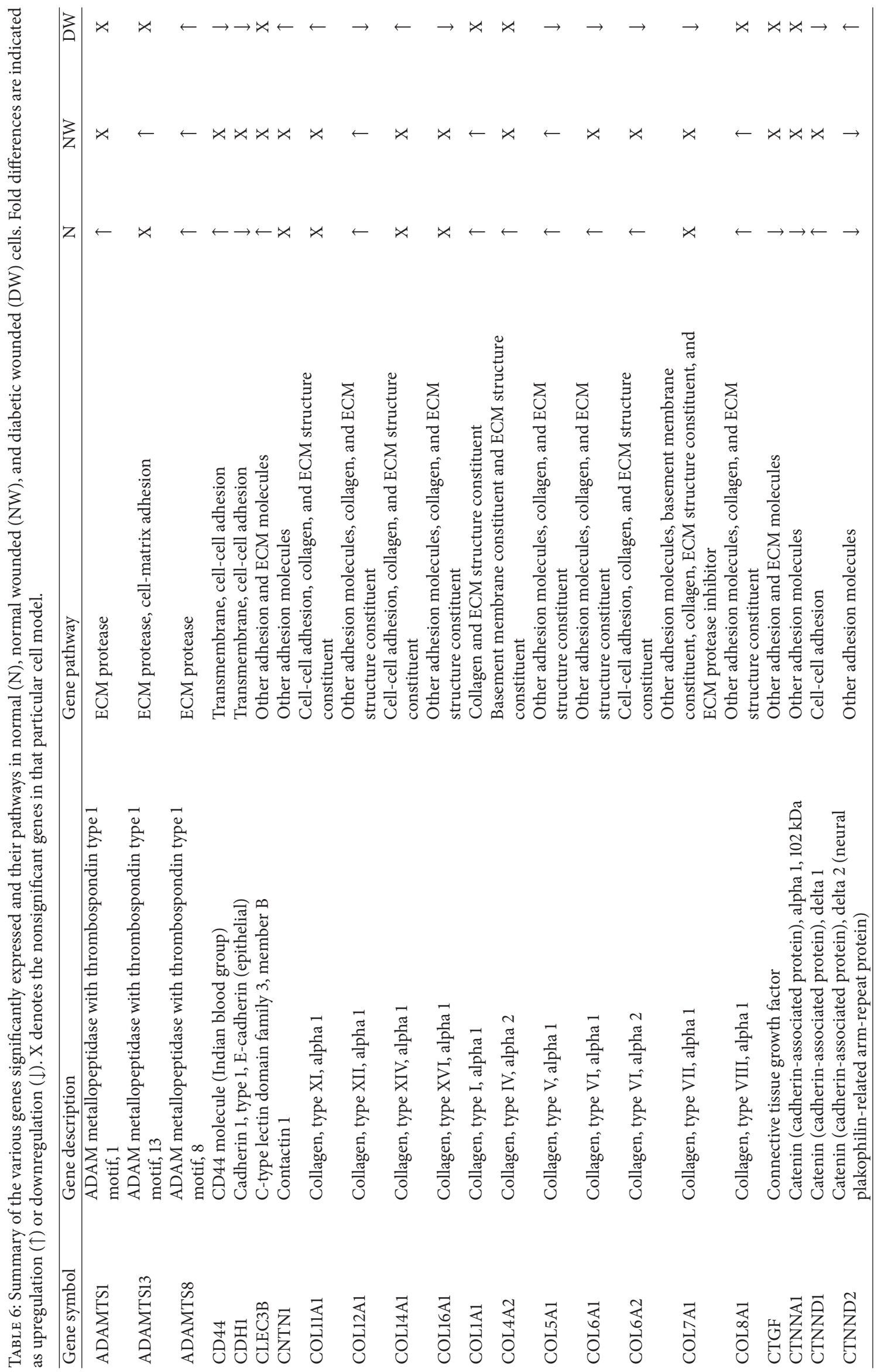




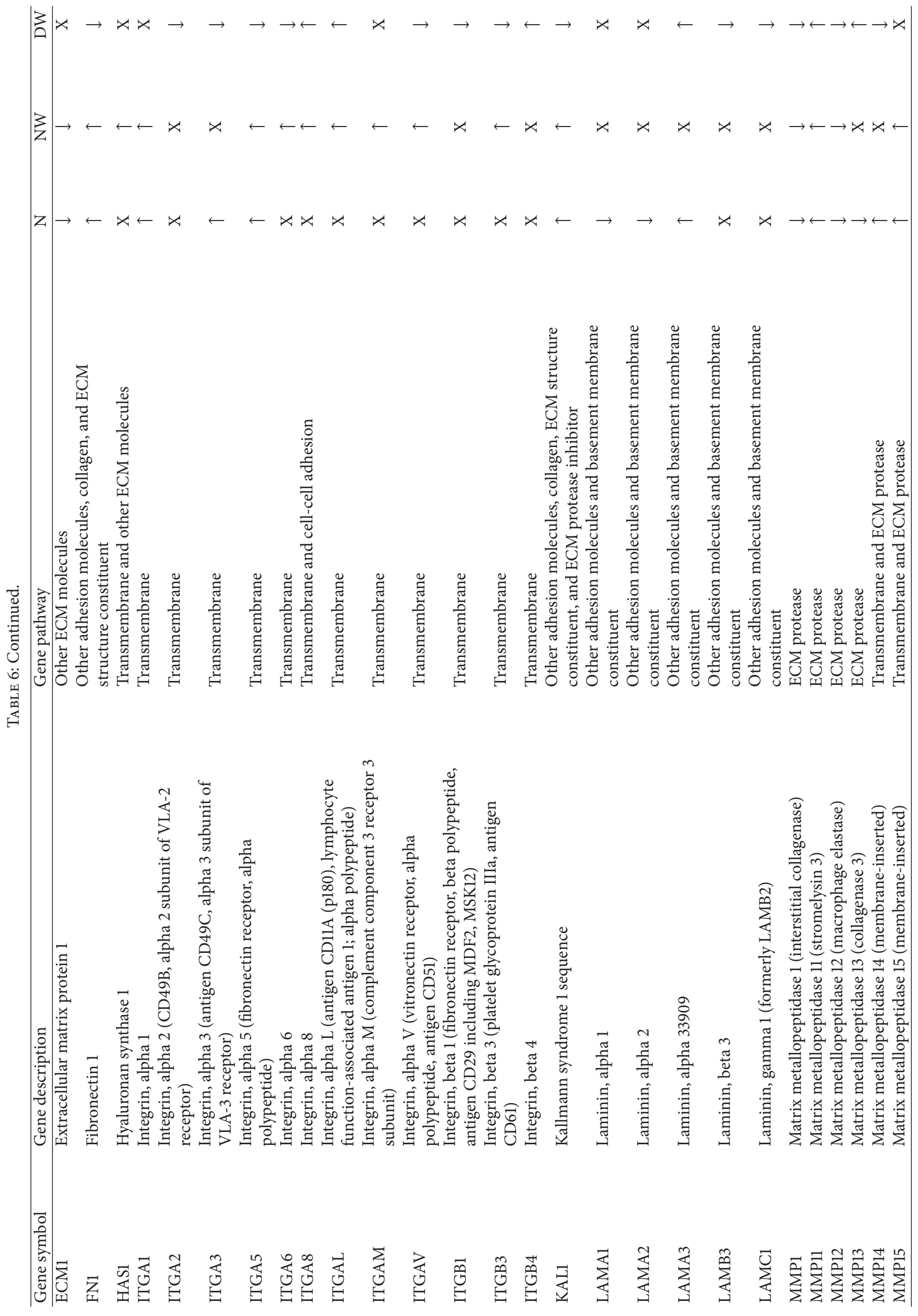




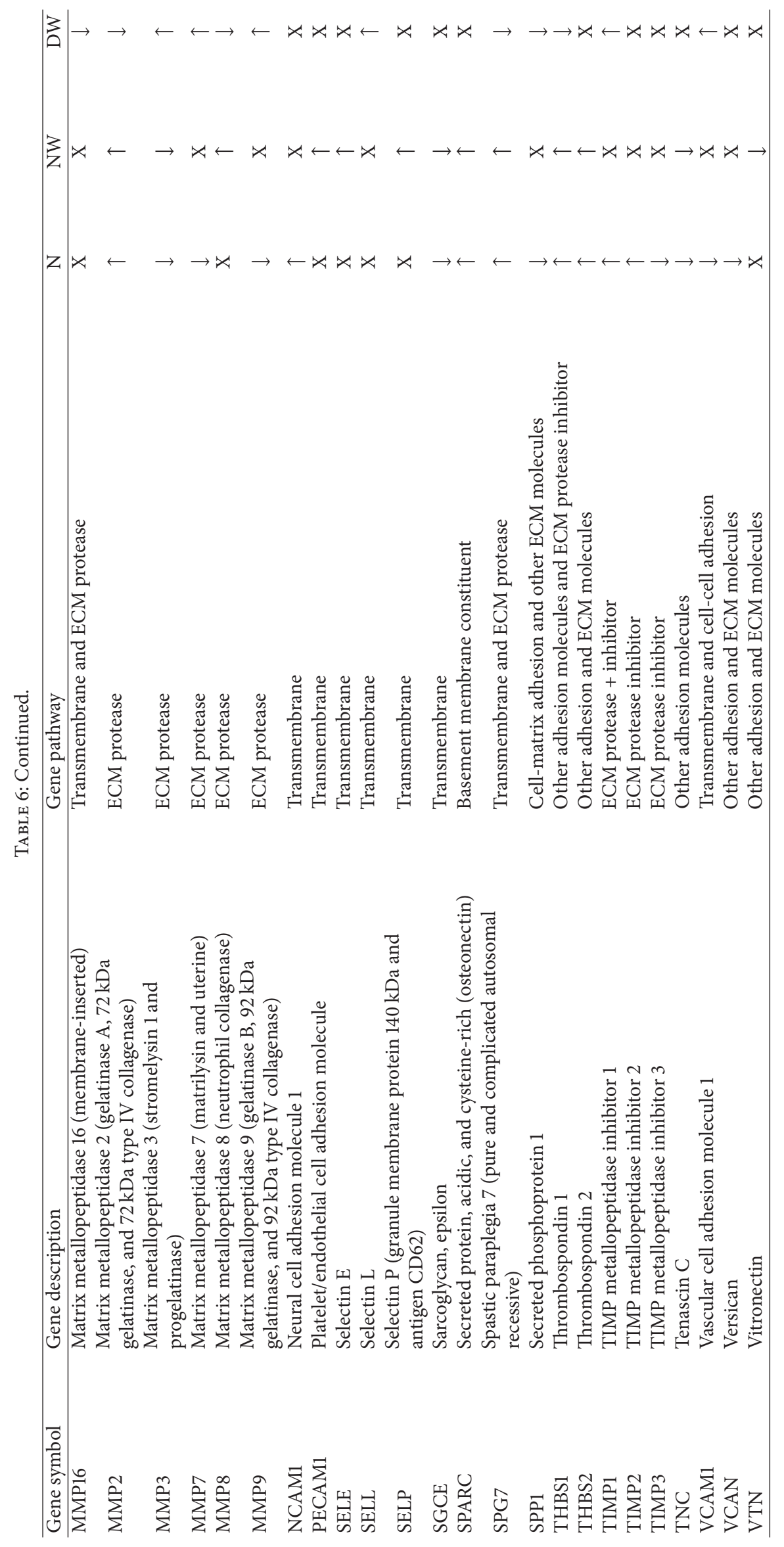


hyperglycaemia. Also in chronic wounds, the inflammatory phase is normally delayed, which promotes increased levels of proteases such as MMPs, causing destruction of the ECM, and damages growth factors as well as receptors essential in the healing process. This also results in a lack of integrins which bind to $\mathrm{FN}$ to enhance migration, and hence the decrease in migration [52, 53]. Furthermore MMP3, MMP7, MMP9, MMP11, and MMP13 were upregulated in DW cells irradiated at $660 \mathrm{~nm}$. This is possibly due to the fact that degraded collagen molecules do not interact properly enabling a disorganised and weak ECM, increasing the levels of some MMPs in chronic wounds [54]. This corresponds with the decrease in Col-I seen in these cells [21]. However, there was a significant upregulation of some of the collagens and other essential ECM proteins, which is in line with the increase in collagen seen in irradiated DW cells [20].

In conclusion, photobiomodulation at a wavelength of $660 \mathrm{~nm}$ enhances gene expression of proteins involved in the ECM. The profile is dependent on the culture conditions and stressors placed on the cells. Increased glucose concentration in the culture media was associated with impaired gene regulation, which could be accountable for the poor response of these cells seen in wound healing. Previous studies have not exploited the role of LILI in gene expression of proteins in the ECM using fibroblast cells in vitro. This study was able to show the gene profile in normal and diabetic wound healing in vitro. The results also confirm the very important role exhibited by cell adhesion molecules (CAMs), integrins, ECM proteins, proteases, and inhibitors in wound healing. Therefore LILI mediated gene expression in wounded fibroblasts through paracrine and autocrine interactions to enhance wound healing. Further work on the molecular advances of gene modulation and their receptors will elucidate the therapeutic importance of LILI.

\section{Disclosure}

The material in this research paper has neither been published nor is being considered elsewhere for publication.

\section{Conflict of Interests}

There is no conflict of interests regarding the publication of this paper.

\section{References}

[1] M. S. Ågren and M. Werthén, "The extracellular matrix in wound healing: a closer look at therapeutics for chronic wounds," International Journal of Lower Extremity Wounds, vol. 6, no. 2, pp. 82-97, 2007.

[2] G. S. Schultz, G. Ladwig, and A. Wysocki, "World wide wounds," 2005 http://www.worldwidewounds.com/.

[3] M. S. Agren, W. H. Eaglstein, M. W. J. Ferguson et al., "Causes and effects of the chronic inflammation in venous leg ulcers," Acta Dermato-Venereologica, Supplement, no. 210, pp. 3-17, 2000 .
[4] S. F. Badylak, "The extracellular matrix as a scaffold for tissue reconstruction," Seminars in Cell and Developmental Biology, vol. 13, no. 5, pp. 377-383, 2002.

[5] K. J. Rolfe and A. O. Grobbelaar, "The growth receptors and their role in wound healing," Current Opinion in Investigational Drugs, vol. 11, no. 11, pp. 1221-1228, 2010.

[6] J. W. Penn, A. O. Grobbelaar, and K. J. Rolfe, "The role ofthe TGF-beta family in wound healing, burns and scarring a review," International Journal of Burns and Trauma, no. 1, pp. $18-28,2012$.

[7] B. Eckes, R. Nischt, and T. Krieg, "Cell-matrix interactions in dermal repair and scarring," Fibrogenesis and Tissue Repair, vol. 3, no. 1, article 4, 2010.

[8] W. P. Daley, S. B. Peters, and M. Larsen, "Extracellular matrix dynamics in development and regenerative medicine," Journal of Cell Science, vol. 121, no. 3, pp. 255-264, 2008.

[9] J. J. Tomasek, G. Gabbiani, B. Hinz, C. Chaponnier, and R. A. Brown, "Myofibroblasts and mechano: regulation of connective tissue remodelling," Nature Reviews Molecular Cell Biology, vol. 3, no. 5, pp. 349-363, 2002.

[10] D. J. Abraham, B. Eckes, V. Rajkumar, and T. Krieg, "New developments in fibroblast and myofibroblast biology: implications for fibrosis and scleroderma," Current Rheumatology Reports, vol. 9, no. 2, pp. 136-143, 2007.

[11] E. G. Neilson, "Mechanisms of disease: Fibroblasts. A new look at an old problem," Nature Clinical Practice Nephrology, vol. 2, no. 2, pp. 101-108, 2006.

[12] P. Price, K. Fogh, C. Glynn, D. L. Krasner, J. Osterbrink, and R. G. Sibbald, "Managing painful chronic wounds: the wound pain management model," International Wound Journal, vol. 4, supplement 1, pp. 4-15, 2007.

[13] K. Soon and C. Acton, "Pain-induced stress: a barrier to wound healing," Wounds, vol. 2, no. 4, pp. 92-101, 2006.

[14] S. Ryan, C. Eager, and R. G. Sibbald, "Venous leg ulcer pain," Ostomy/Wound Management, vol. 49, no. 4, supplement, pp. 1623, 2003.

[15] I. Anderson, "Aetiology, assessment and management of leg ulcers," Wound Essentials, vol. 1, pp. 20-36, 2006.

[16] J. Kantor and D. J. Margolis, "Epidemiology: leg ulcers," in $A$ Problem-Based Learning Approach, M. J. Morison, C. J. Moffatt, and P. J. Franks, Eds., pp. 65-73, Mosby, London, UK, 2007.

[17] J. R. Mekkes, M. A. M. Loots, A. C. Van Der Wal, and J. D. Bos, "Causes, investigation and treatment of leg ulceration," British Journal of Dermatology, vol. 148, no. 3, pp. 388-401, 2003.

[18] D. H. Evans and H. Abrahamse, "A review of laboratory-based methods to investigate second messengers in low-level laser therapy (LLLT)," Medical Laser Application, vol. 24, no. 3, pp. 201-215, 2009.

[19] M. Simões Ribeiro, D. D. F. Teixeira Da Silva, C. E. Nabuco De Araújo et al., "Effects of low-intensity polarized visible laser radiation on skin burns: a light microscopy study," Journal of Clinical Laser Medicine and Surgery, vol. 22, no. 1, pp. 59-66, 2004.

[20] S. M. Ayuk, N. N. Houreld, and H. Abrahamse, "Collagen production in diabetic wounded fibroblasts in response to lowintensity laser irradiation at $660 \mathrm{~nm}$," Diabetes Technology and Therapeutics, vol. 14, no. 12, pp. 1110-1117, 2012. 
[21] R. Lubart, M. Eichler, R. Lavi, H. Friedman, and A. Shainberg, "Low-energy laser irradiation promotes cellular redox activity," Photomedicine and Laser Surgery, vol. 23, no. 1, pp. 3-9, 2005.

[22] M. Eichler, R. Lavi, A. Shainberg, and R. Lubart, "Flavins are source of visible-light-induced free radical formation in cells," Lasers in Surgery and Medicine, vol. 37, no. 4, pp. 314-319, 2005.

[23] K. Plaetzer, T. Kiesslich, B. Krammer, and P. Hammerl, "Characterization of the cell death modes and the associated changes in cellular energy supply in response to AlPcS4-PDT," Photochemical and Photobiological Sciences, vol. 1, no. 3, pp. 172-177, 2002.

[24] P. V. Peplow, T.-Y. Chung, B. Ryan, and G. D. Baxter, "Laser photobiostimulation of wound healing: reciprocity of irradiance and exposure time on energy density for splinted wounds in diabetic mice," Lasers in Surgery and Medicine, vol. 43, no. 8, pp. 843-850, 2011.

[25] H. Y. Chang, J.-T. Chi, S. Dudoit et al., "Diversity, topographic differentiation, and positional memory in human fibroblasts," Proceedings of the National Academy of Sciences of the United States of America, vol. 99, no. 20, pp. 12877-12882, 2002.

[26] N. Houreld and H. Abrahamse, "Irradiation with a $632.8 \mathrm{~nm}$ helium-neon laser with $5 \mathrm{~J} / \mathrm{cm}^{2}$ stimulates proliferation and expression of interleukin-6 in diabetic wounded fibroblast cells," Diabetes Technology and Therapeutics, vol. 9, no. 5, pp. 451-459, 2007.

[27] G. Cory, "Scratch-wound assay," Methods in Molecular Biology, vol. 769, pp. 25-30, 2011.

[28] K. P. Goetsch and C. U. Niesler, "Optimization of the scratch assay for in vitro skeletal muscle wound healing analysis," Analytical Biochemistry, vol. 411, no. 1, pp. 158-160, 2011.

[29] G. S. Schultz and A. Wysocki, "Interactions between extracellular matrix and growth factors in wound healing," Wound Repair and Regeneration, vol. 17, no. 2, pp. 153-162, 2009.

[30] K. S. Midwood, L. V. Williams, and J. E. Schwarzbauer, "Tissue repair and the dynamics of the extracellular matrix," International Journal of Biochemistry and Cell Biology, vol. 36, no. 6, pp. 1031-1037, 2004.

[31] T. Okegawa, R.-C. Pong, Y. Li, and J.-T. Hsieh, “The role of cell adhesion molecule in cancer progression and its application in cancer therapy," Acta Biochimica Polonica, vol. 51, no. 2, pp. 445457, 2004.

[32] R. O. Hynes, "Integrins: bidirectional, allosteric signaling machines," Cell, vol. 110, no. 6, pp. 673-687, 2002.

[33] T. Yagi and M. Takeichi, "Cadherin superfamily genes: functions, genomic organization, and neurologic diversity," Genes and Development, vol. 14, no. 10, pp. 1169-1180, 2000.

[34] G. Maheshwari, G. Brown, D. A. Lauffenburger, A. Wells, and L. G. Griffith, "Cell adhesion and motility depend on nanoscale RGD clustering," Journal of Cell Science, vol. 113, no. 10, pp. 16771686, 2000.

[35] R. L. Juliano, "Signal transduction by cell adhesion receptors and the cytoskeleton: functions of integrins, cadherins, selectins, and immunoglobulin-superfamily members," Annual Review of Pharmacology and Toxicology, vol. 42, pp. 283-323, 2002.

[36] L. Petruzzelli, M. Takami, and H. D. Humes, "Structure and function of cell adhesion molecules," The American Journal of Medicine, vol. 106, no. 4, pp. 467-476, 1999.
[37] J. Myllyharju and K. I. Kivirikko, "Collagens, modifying enzymes and their mutations in humans, flies and worms," Trends in Genetics, vol. 20, no. 1, pp. 33-43, 2004.

[38] J. Sottile and D. C. Hocking, "Fibronectin polymerization regulates the composition and stability of extracellular matrix fibrils and cell-matrix adhesions," Molecular Biology of the Cell, vol. 13, no. 10, pp. 3546-3559, 2002.

[39] T. Velling, J. Risteli, K. Wennerberg, D. F. Mosher, and S. Johansson, "Polymerization of type I and III collagens is dependent on fibronectin and enhanced by integrins $\alpha 11 \beta 1$ and $\alpha 2 \beta 1$," Journal of Biological Chemistry, vol. 277, no. 40, pp. 37377-37381, 2002.

[40] K. E. Kadler, C. Baldock, J. Bella, and R. P. Boot-Handford, "Collagens at a glance," Journal of Cell Science, vol. 120, no. 12, pp. 1955-1958, 2007.

[41] A. D. Bradshaw, D. C. Graves, K. Motamed, and E. H. Sage, "SPARC-null mice exhibit increased adiposity without significant differences in overall body weight," Proceedings of the National Academy of Sciences of the United States of America, vol. 100, no. 10, pp. 6045-6050, 2003.

[42] M. Seux, S. Peuget, M. P. Montero et al., "TP53INP1 decreases pancreatic cancer cell migration by regulating SPARC expression," Oncogene, vol. 30, no. 27, pp. 3049-3061, 2011.

[43] M. Koppen, M. D. Metodiev, G. Casari, E. I. Rugarli, and T. Langer, "Variable and tissue-specific subunit composition of mitochondrial m-AAA protease complexes linked to hereditary spastic paraplegia," Molecular and Cellular Biology, vol. 27, no. 2, pp. 758-767, 2007.

[44] Z. Li, S. Guo, F. Yao, Y. Zhang, and T. Li, "Increased ratio of serum matrix metalloproteinase- 9 against TIMP-1 predicts poor wound healing in diabetic foot ulcers," Journal of Diabetes and Its Complications, vol. 27, no. 4, pp. 380-382, 2013.

[45] T. R. Kyriakides, D. Wulsin, E. A. Skokos et al., "Mice that lack matrix metalloproteinase-9 display delayed wound healing associated with delayed reepithelization and disordered collagen fibrillogenesis," Matrix Biology, vol. 28, no. 2, pp. 65-73, 2009.

[46] V. Masson, L. Rodriguez De La Ballina, C. Munaut et al., "Contribution of host MMP-2 and MMP-9 to promote tumor vascularization and invasion of malignant keratinocytes," The FASEB Journal, vol. 19, no. 2, pp. 234-236, 2005.

[47] G. Bix and R. V. Iozzo, "Matrix revolutions: "Tails" of basementmembrane components with angiostatic functions," Trends in Cell Biology, vol. 15, no. 1, pp. 52-60, 2005.

[48] Y. Hamano, M. Zeisberg, H. Sugimoto et al., "Physiological levels of tumstatin, a fragment of collagen IV $\alpha 3$ chain, are generated by MMP-9 proteolysis and suppress angiogenesis via $\alpha$ V 33 integrin," Cancer Cell, vol. 3, no. 6, pp. 589-601, 2003.

[49] J. P. Hodde and C. E. Johnson, "Extracellular matrix as a strategy for treating chronic wounds," The American Journal of Clinical Dermatology, vol. 8, no. 2, pp. 61-66, 2007.

[50] A. H. Hsieh, C. M.-H. Tsai, M. Qing-Jun et al., “Timedependent increases in type-III collagen gene expression in medial collateral ligament fibroblasts under cyclic strains," Journal of Orthopaedic Research, vol. 18, no. 2, pp. 220-227, 2000.

[51] R. P. Butt and J. E. Bishop, "Mechanical load enhances the stimulatory effect of serum growth factors on cardiac fibroblast procollagen synthesis," Journal of Molecular and Cellular Cardiology, vol. 29, no. 4, pp. 1141-1151, 1997. 
[52] M. Muller, C. Trocme, B. Lardy, F. Morel, S. Halimi, and P. Y. Benhamou, "Matrix metalloproteinases and diabetic foot ulcers: the ratio of MMP-1 to TIMP-1 is a predictor of wound healing," Diabetic Medicine, vol. 25, no. 4, pp. 419-426, 2008.

[53] K. C. Ongenae, T. J. Phillips, and H.-Y. Park, "Level of fibronectin mRNA is markedly increased in human chronic wounds," Dermatologic Surgery, vol. 26, no. 5, pp. 447-451, 2000.

[54] R. Lobmann, C. Zemlin, M. Motzkau, K. Reschke, and H. Lehnert, "Expression of matrix metalloproteinases and growth factors in diabetic foot wounds treated with a protease absorbent dressing," Journal of Diabetes and Its Complications, vol. 20, no. 5, pp. 329-335, 2006. 

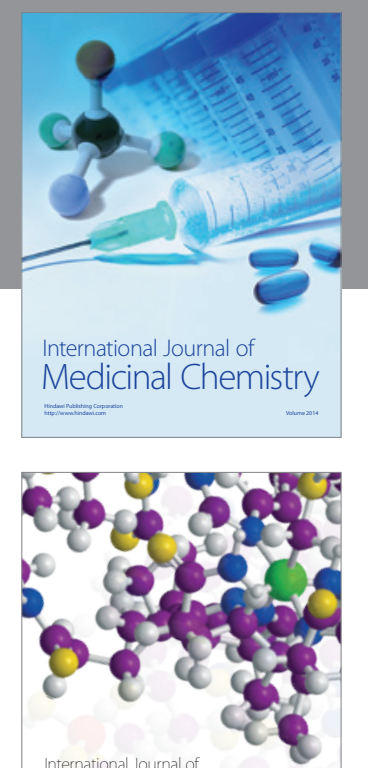

\section{Carbohydrate} Chemistry

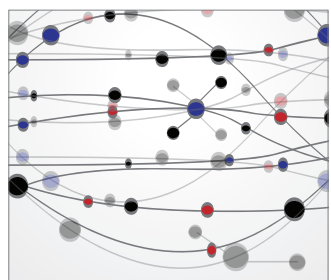

The Scientific World Journal
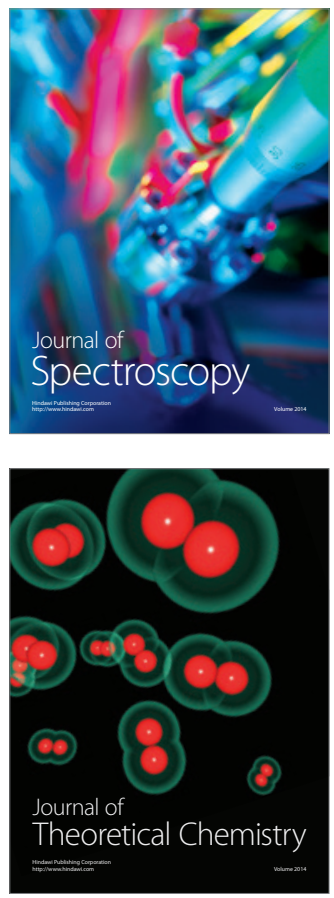
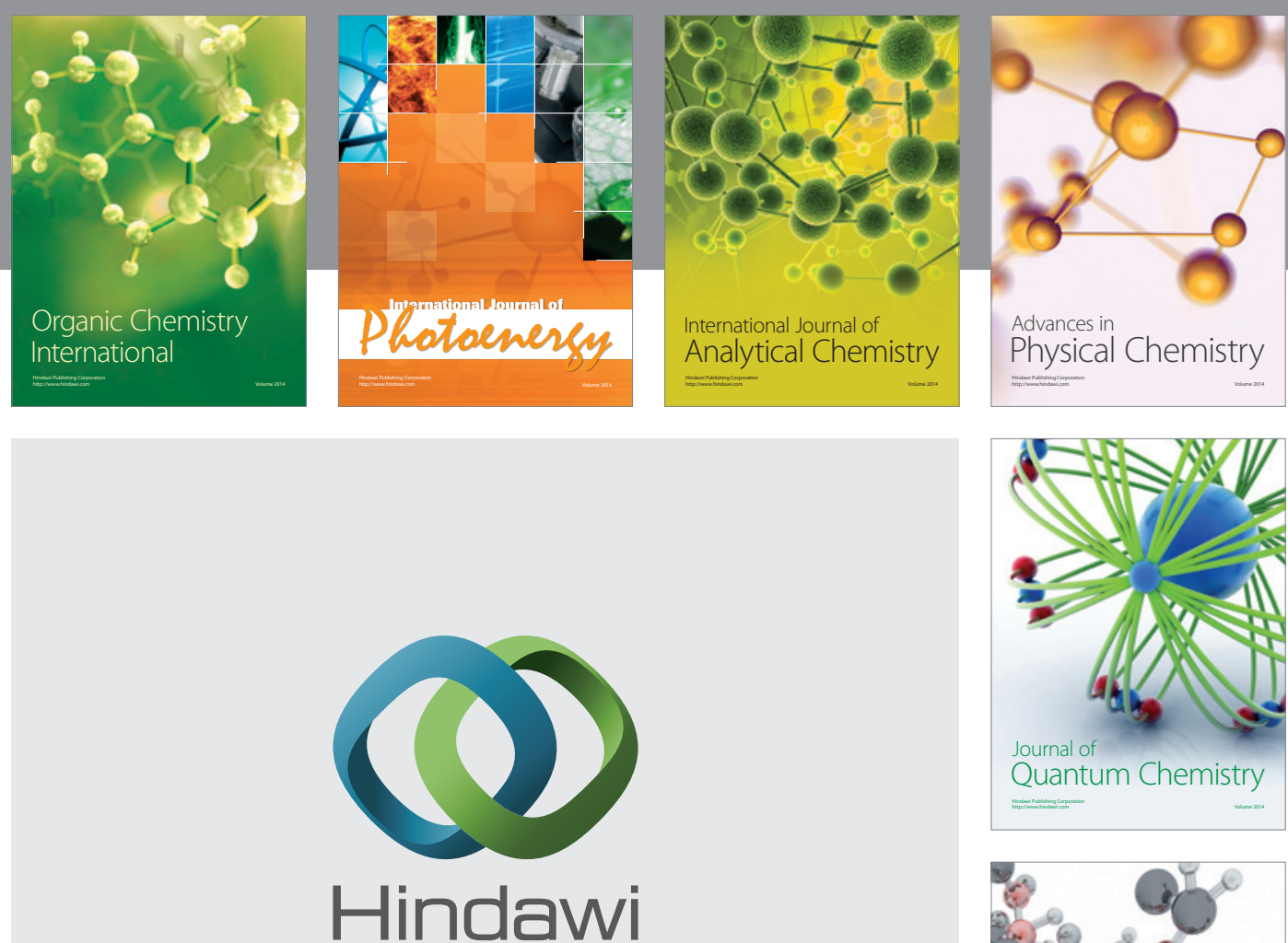

Submit your manuscripts at

http://www.hindawi.com

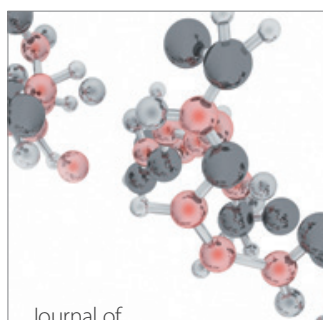

Analytical Methods

in Chemistry

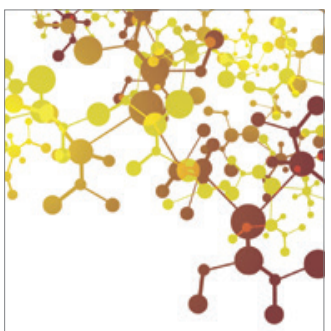

Journal of

Applied Chemistry

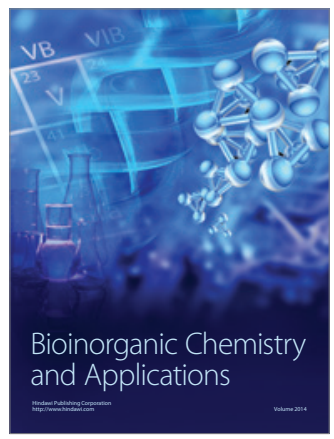

Inorganic Chemistry
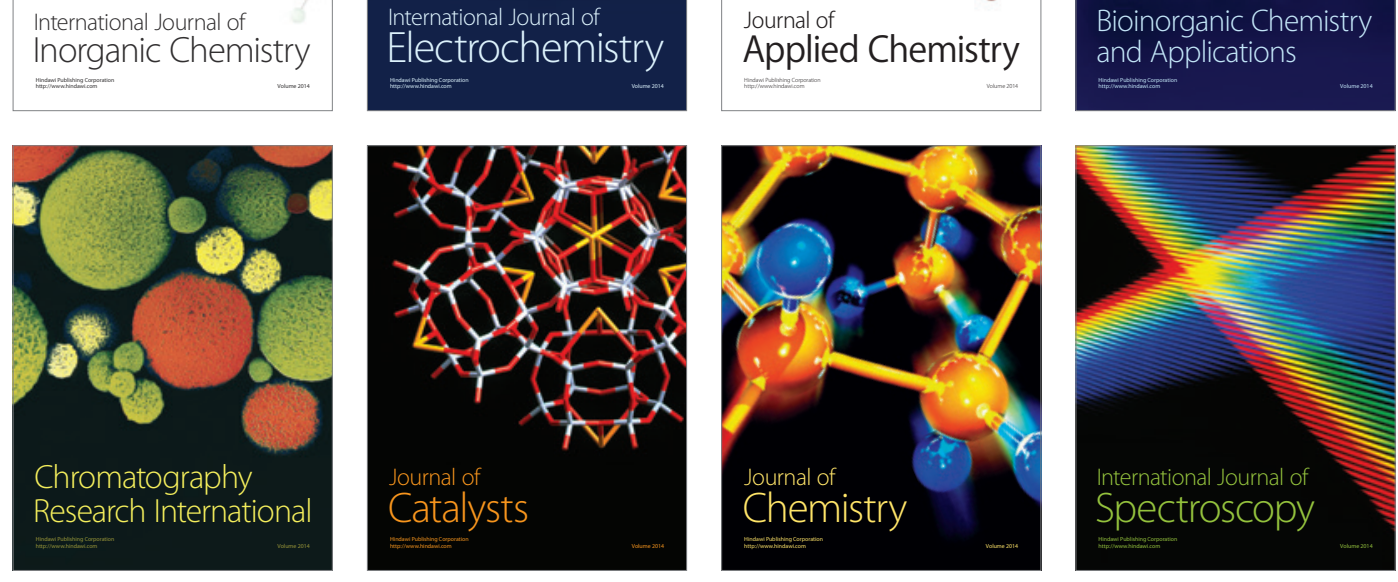